www.volsu.ru

DOI: http://doi.org/10.15688/nav.jvolsu.2016.1.4

UDC 572(470.45):902/904

LBC $28.71+63.442(235.54)$

\title{
ON THE ANTHROPOLOGY OF THE POPULATION \\ OF THE ENEOLITHIC - EARLY BRONZE AGE (ON MATERIALS OF BURIAL GROUNDS OF THE VOLGOGRAD REGION) ${ }^{1}$
}

\author{
Mariya A. Balabanova \\ Volgograd State University, Volgograd, Russian Federation
}

\begin{abstract}
This article is devoted to the results of anthropological studies of craniological materials which were found in the burial complexes of the Eneolithic and the Early Bronze age in the Volgograd region. The number of discovered skulls is twenty six, two of them belong to the Eneolithic, four male and two female skulls pertain to the early period of the Yamna culture and the others belong to the late period of the Yamna culture. Except for the new materials, seven skulls were published by B.V. Fershteyn and V.V. Ginzburg. A.V. Kiyashko obtained them after the preliminary check of cultural and chronological origins.

The results of the craniological research showed that the found artifacts are not homogenous but the massive dolicho-mesocraniological type prevails in the series of both early and late stages. The author gives their morphological characteristics and describes their connection with the craniological complexes of Eneolithic-bronze period of Eastern Europe. This connection is indicated by Eneolithic Khvalynsk culture and the Yamna culture of the early Bronze Age.

Key words: the Yamna culture, Eneolithic, proto- mediterranean type, burial complex, mound, zygomatic diameter, the angle of the nose protrusion, canonical analysis.
\end{abstract}

УДК 572(470.45):902/904

ББК $28.71+63.442(235.54)$

\section{К АНТРОПОЛОГИИ НАСЕЛЕНИЯ ЭНЕОЛИТА - РАННЕЙ БРОНЗЫ (ПО МАТЕРИАЛАМ МОГИЛЬНИКОВ ВОЛГОГРАДСКОЙ ОБЛАСТИ) ${ }^{1}$}

\author{
Мария Афанасьевна Балабанова \\ Волгоградский государственный университет, г. Волгоград, Российская Федерация
}

\begin{abstract}
Аннотация. В статье приводятся результаты антропологического исследования краниологических материалов эпохи энеолита - ранней бронзы из могильников Волгоградской области. Серия насчитывает 26 черепов, из которых 2 черепа относятся к эпохе энеолита, 4 мужских и 2 женских черепа - к раннему этапу ямной культуры, а остальные черепа относятся к позднему этапу ямной культуры. Кроме новых материалов, в серии 7 черепов, опубликованных Б.В. Фирштейн и В.В. Гинзбургом. Такое их количество было получено А.В. Кияшко после предварительной проверки культурно-хронологической принадлежности.

Результаты краниологического исследования показали, что серия в целом неоднородна, но преобладает массивный долихо-мезокранный тип как в серии раннего этапа, так и позднего. Приводится их морфологическая характеристика, рассматриваются связи с краниологическими комплексами энеолита - бронзы Восточной Европы. Отмечается их связь с носителями как хвалынской энеолитической культуры, так и ямной, катакомбной и полтавкинской культур бронзового века.

Ключевые слова: ямная культура, энеолит, протосредиземноморский тип, погребение, курган, скуловой диаметр, угол выступания носа, канонический анализ.
\end{abstract}

Антропологические материалы по населению энеолита-ранней бронзы Нижнего Поволжья изучали Г.Ф. Дебец [1936; 1948],
В.В. Гинзбург [1959], Н.М. Глазкова, В.П. Чтецов [1960], Б.В. Фирштейн [1967], А.В. Шевченко [1986], А.А. Казарницкий [2012] и 
А.А. Хохлов [2013]. К сожалению, в опубликованных сериях материал из могильников Волгоградской области представлен единичными черепами. Более того, как показали результаты проверки культурно-хронологической принадлежности опубликованных черепов, их оказалось еще меньше. Еще Г.Ф. Дебец [Дебец, 1948, с. 102-104], описывая небольшую серию черепов из могильников Нижнего Поволжья, отмечает следующее:

1) серия однородна;

2) сильно выступающий нос;

3) сильно наклонный лоб;

4) мощное надбровье;

5) высокий рост.

Морфологию восьми черепов из калиновского могильника дает В.В. Гинзбург [Гинзбург, 1959, с. 525-534]. Правда, как оказалось, только один мужской череп из погребения 43 кургана 8 относится к позднеямному времени, остальные были атрибутированы эпохой средней бронзы (волго-донской вариант катакомбной культуры, полтавкинская культура и др.). Череп из погребения 43 кургана 8 принадлежал мужчине возмужалого возраста и сочетал в своем морфологическом облике мезокранный тип со средненаклонным лбом, узким, низким, резко профилированным в горизонтальной плоскости лицом. Данное сочетание признаков, по мнению автора публикации, позволяет определить его тип как степной.

Из списка черепов ямной культуры могильника Политотдельское, изученных Н.М. Глазковой и В.П. Чтецовым (1960), по мнению А.В. Кияшко, нет ни одного, который можно было бы отнести к ранней бронзе.

Что касается краниологической серии, опубликованной Б.В. Фирштейн [Фирштейн, 1967, c. 102] и полученной в результате раскопок Сталинградской экспедиции, то при описании морфологического облика «ямников» исследователь отметила, что все черепадолихокранные, крупные, среднемассивные, с хорошо развитым рельефом. Лицо мезоморфного строения и по скуловой ширине, и по верхней высоте с резкой горизонтальной профилировкой, кроме черепа из погребения 10 кургана 9 Бережновка II, у которого лицо умерено профилировано. По типологической характеристике три черепа Б.В. Фирштейн относит к протосредиземноморскому типу (по- гребение 20 кургана 5 Бережновки I; погребение 5 кургана 9 Бережновки II и погребение 5 кургана 29), а морфологический тип мужского черепа из погребения 22 кургана 5 Бережновки I и двух женских черепов из погребений 9 и 16 кургана 9 Бережновки II определяет как средиземноморский.

Кроме того, на двух мужских черепах (зрелого возраста и 14-16 лет) она обнаружила трепанационные отверстия без следов облитерации.

А.В. Шевченко в своей работе 1986 г., решая проблему происхождения племен ямной культуры, использует в сопоставлениях и бережновскую группу, происхождение которой, по его мнению, связано с населением Придунавья [Шевченко, 1986, с. 158-161]. С его точкой зрения не согласен А.А. Хохлов, который считает, что морфологические черты, характерные для бережновской группы, могут быть связаны не с западом, а с Предкавказьем и временем контактов между носителями раннеямной и майкопской культур [Хохлов, 2013, c. 198]. К этому выводу он пришел, изучив бережновскую серию после тщательной идентификации погребений с конкретными археологическими комплексами. А.А. Хохлов выяснил, что два черепа из списка Б.В. Фирштейн (погребение 20 кургана 5 Бережновки I и погребение 5 кургана 29 Бережновки II), учтенных как принадлежащие к ямной культуpe, определяются другим временем ${ }^{2}$ [Хохлов, 2013, с. 196]. Проблему происхождения бережновской группы с учетом новых материалов и разработок в археологической науке А.А. Хохлов решает при помощи сравнения ее с хвалынской энеолитической серией и отмечает их сходство [Хохлов, 2013, с. 167]. По его мнению, «в период проживания населения, оставившего в Нижнем Поволжье так называемые древнейшие подкурганные захоронения, существовали контакты между постхвалынскими группами и западными, видимо, как-то связанными со среднестоговской культурной традицией». Появление же в ямное время на территории Волго-Уралья черепов, сочетающих массивность и гиперморфность, связывает с притоком на эту территорию генофонда носителей западных от Волги культур [Хохлов, 2013, с. 198].

Таким образом, до сих пор были опубликованы лишь единичные черепа из погре- 
бений эпохи энеолита - ранней бронзы с территории Волгоградской области, и поэтому назрела необходимость их публикации.

Материал исследования. На настоящий момент серия насчитывает 21 мужской и 5 женских черепов (см. табл. 1). Антропологический материал собирался на протяжении нескольких десятилетий в результате раскопок могильников на территории Волгоградской области. Группа по культурному и хронологическим признакам неоднородная и включает в себя два черепа, относящихся к эпохе энеолита, и, несмотря на плохую сохранность, стоит их рассмотреть отдельно; четыре мужских черепа и два женских относятся к раннему этапу ямной культуры, а остальная часть относится к позднеямному пласту.

\section{Описание материала}

Эпоха энеолита. К этой эпохе относятся мужские черепа из погребения 3 кургана 3 могильника Шляховский I и из погребения 7 кургана 13 могильника Перегрузное I. Череп из погребения 3 кургана 3 могильника Шляховский принадлежал мужчине, который в момент смерти находился в возрасте около 40-45 лет. Череп плохо сохранился, но видно, что мозговая коробка очень длинная и очень широкая. Степень выраженности рельефа на костях выше средней.

Череп из погребения 7 кургана 13 могильника Перегрузное $\mathbf{I}^{3}$ принадлежал молодому мужчине, который на момент смерти находился в возрасте 20-25 лет. Его мозговая коробка длинная, среднеширокая с долихокранной пропорцией. Места прикрепления мышц, сухожилий и фасций с хорошо развитым рельефом. Вертикальная норма черепа имеет близкую к сфеноиду форму. Основание черепа очень широкое. Лобная кость широкая по наименьшей ширине и узкая по наибольшей. Теменная хорда и дуга короткие; затылочная хорда и дуга длинные. Затылочно-теменной индекс очень большой [Беневоленская, 1980].

Лицевой отдел широкий по значению верхней ширины. Альвеолярная дуга и нос среднеширокие.

Обследование черепной капсулы позволило зафиксировать на внешней ее поверхно- сти признаки воздействия низких температур. На всех костях свода черепа наблюдается васкулярная реакция, интенсивность которой определяется в пределах 3 баллов. На эндокране в области теменных костей выявлены сильно выраженные пальцевидные вдавления, а на лобной кости имеются веретенообразные возвышения и образования, которые располагаются по обеим сторонам от лобного синуса.

Что касается патологических изменений на посткраниальном скелете, то на тазовых костях в области вертлужной впадины удалось обнаружить следы изношенности. Ее суставная поверхность сильно стерта, что маркирует развитие дегенеративного заболевания ${ }^{4}$.

Раннеямная эпоха. Мужская серия насчитывает 4 черепа относительно хорошей сохранности. Из них два черепа из могильника Бережновка, которые были опубликованы Б.В. Фирштейн [1967], а затем и А.А. Хохловым [2013]. Черепа из бережновского могильника в данной работе отдельно не рассматриваются, так как подробный анализ их морфологии был проделан моими предшественниками, поэтому рассмотрим только череп из погребения 5 кургана 14 могильника Писаревка II и второй череп из могильника Аксай I, курган 9, погребение 8.

Череп из погребения 5 кургана 14 могильника Писаревка II принадлежал мужчине 35-40 лет (рис. 1,1; строка 1 табл. 1). Его мозговая коробка длинная, широкая и средневысокая с мезокранной, ортокранной и тапейнокранной пропорциями. Область переносья, надбровные дуги, наружный затылочный бугор и сосцевидные отростки хорошо выражены. Форма черепа сверху ближе к овоидной. Основание черепа длинное и широкое. Лобная кость по наименьшей ширине широкая, а по наибольшей ширине средняя, с плоским профилем по линии фронтотемпоральных точек и покатым по линии назион - метопион. Лобная и теменная дуга и хорда средней длины. Затылочная кость широкая, с дугой и хордой средней длины.

Лицо очень широкое по значению всех трех широтных размеров $(45 ; 43 ; 46$ - размеры по Мартину). Его верхняя и полная высота средняя с ослабленной горизонтальной профилировкой по значению назомалярного угла и резкой по значению зигомаксилярного угла. 
Вертикальный профиль лицевого отдела с тенденцией к мезогнатии. Альвеолярная дуга и небо широкие и длинные; нос высокий и широкий как по абсолютным размерам, так и по указателю (платиринный), с антроппинной формой нижнего края грушевидного отверстия; передненосовая ость выражена ниже среднего. Глазница широкая и низкая по абсолютной высоте и среднеширокая (мезоконхная) по указателю. Переносье по дакриальным размерам очень широкое и высокое, а носовые кости средней ширины и высокие, резко выступающие к линии профиля. Клыковая ямка средней глубины (табл. 1).

Череп из могильника Аксай I, курган 9, погребение 8, принадлежал мужчине около 50 лет и был извлечен из могилы, которая была сооружена по типу вторичных захоронений (строка 2 табл. 1). Отдельные части скелета находились не в анатомическом порядке [Дьяченко, 1999, с. 104, 105, рис. 14,4].

Мозговой отдел черепа длинный, узкий и очень высокий с долихокранной, гипсикранной и акрокранной пропорциями. Область переносья, надбровные дуги, наружный затылочный бугор и сосцевидные отростки развиты выше среднего. Форма черепа сверху ближе к эллипсоидной. Основание черепа длинное и широкое. По наименьшей ширине лобная кость средняя, а по наибольшей - узкая. Ее угол поперечного изгиба резкий, а угол от назион метопион почти прямой. Лобная и теменная дуга и хорда средней длины, затылочная дуга и хорда длинные.

Лицевой скелет широкий и высокий, с резкой горизонтальной профилировкой на уровне глазниц и ортогнатной вертикальной профилировкой. Нос высокий, с антропинной формой нижнего края грушевидного отверстия, а глазница широкая и низкая как по абсолютной высоте, так и по указателю. И переносье по максилофронтальным размерам, и носовые кости по симотическим размерам очень широкие и высокие с большим углом выступания. Клыковая ямка мелкая.

Рассматривая мужскую серию из раннеямных погребений в целом, следует сказать, что она характеризуется длинной, среднеширокой и высокой мозговой коробкой с долихокранной, гипсикранной и акрокранной пропорциями (табл. 2). Основание черепа средней длины и узкое. Рельеф на черепе развит выше среднего. В вертикальной плоскости преобладают эллипсоидные и овоидные формы. Лобная кость и по наименьшей, и по наибольшей ширине средняя, с резким профилем по линии фронтотемпоральных точек и покатая по линии назион - метопион. Лобная и теменная дуга и хорда средней длины. Затылочная кость среднеширокая, с длинной дугой и хордой.

Лицо среднеширокое по значению скулового диаметра и широкое по значениям верхней ширины и узкое по средней ширине. По верхней высоте лицо средневысокое и резко профилированное в горизонтальной плоскости и с тенденцией к мезогнатии в вертикальной. Альвеолярная дуга широкая и длинная; небо длинное и узкое; нос высокий и широкий по абсолютным размерам и мезоринный по указателю с антроппинной формой нижнего края грушевидного отверстия; передненосовая ость выражена средне. Глазница широкая и низкая по абсолютной высоте и хамэконхная по указателю. Переносье по дакриальным размерам очень широкое и высокое, а носовые кости средней ширины и высокие, резко выступающие к линии профиля. Клыковая ямка средней глубины.

Все четыре мужских черепа показывают нормальную внутригрупповую изменчивость, и в целом размах вариаций по всем признакам небольшой. В связи с малочисленностью серии нет возможности проводить более детальный внутригрупповой анализ.

Позднеямная эпоха. Мужская серия насчитывает 15 черепов, а женская - 3. Из них пять черепов были опубликованы ранее: четыре черепа из бережновского могильника, которые А.В. Кияшко относит к позднеямному этапу, и череп из Калиновского могильника. Кроме этого опубликованы и черепа из могильника Перегрузное I [Балабанова и др., 2014]. Ниже приведена индивидуальная характеристика оставшихся черепов, полученных из раскопок последних десятилетий.

Два черепа - мужской и женский - из погребения 9 кургана 1 могильника Майоровский были получены в результате раскопок в 1998 году [Назаров, 1998]. Оба черепа принадлежали молодым людям: мужчине в момент смерти было 20-25 лет, а женщине - 16- 
18 лет. Мужская черепная коробка плохой сохранности и с посмертной деформацией, поэтому удалось измерить лишь часть признаков (строка 3 табл. 1). По абсолютной длине череп укладывается в средние размеры, а по ширине - в большие с брахикранным черепным указателем. Его лобная кость узкая по 9-му размеру и широкая по 10 -му. Угол поперечного изгиба лба резкий. Степень развития области переносья, надбровных дуг, наружного затылочного бугра и сосцевидных отростков не удалось проследить из-за фрагментарности черепа. Форма черепа сверху ближе к сфеноидной. У лобной и теменной костей дуга средней длины, хорда у лобной кости средней длины, у теменной - короткая. Высота изгиба лобной кости большая.

Лицевой скелет узкий по показателям верхней и средней ширины и резко профилированный по назомалярному углу. Нос средней ширины с антропинной формой нижнего края грушевидного отверстия, а глазница низкая и среднеширокая и по абсолютной высоте, и по указателю (мезоконхная). Переносье по максилофронтальным размерам и носовые кости узкие и высокие, клыковая ямка средней глубины. Кроме этого, следует отметить лопатообразность резцов (2 балла) и подглазничный узор, сформированный по типу 2 [Козинцев, 1988].

Женский череп из этого же погребения лучшей сохранности и характеризуется средней длиной, большой шириной и брахикранным указателем (строка 4 табл. 1). Вертикальная норма черепа ближе к сфеноидной, рельеф на черепе развит ниже среднего. Его ушная высота низкая, лобная кость широкая по обоим размерам с углом поперечного изгиба в пределах 138 градусов. Высота изгиба лба, как и у мужчины, большая. Лобная дуга и хорда короткие, а теменная хорда и дуга длинные.

Лицевой скелет широкий по верхней ширине и узкий по средней. Его горизонтальная профилировка на уровне глазниц резкая. Сама глазница широкая и очень низкая, как по абсолютной высоте, так и по указателю (хамэконхная). Переносье по максилофронтальным размерам широкое и относительно низкое, а носовые кости узкие и высокие. Из краниоскопических признаков следует отметить наличие метопизма, надглазничных отверстий: слева одно, а справа - два отверстия. Кроме этого, по лямбдовидному шву имеются многочисленные дополнительные косточки. Подглазничный узор (ПГУ) сформирован по типу 2 [Козинцев, 1988].

Мужской череп из погребения 1 кургана 6 могильника Лебяжье относительно хорошей сохранности сочетал длинную, узкую и высокую мозговую коробку с резко долихокранным, ортокранным и акрокранным указателями (см. строку 5 табл. 1). Череп массивный, эллипсоидной формы, но со слабо развитым наружным затылочным бугром. Лобная кость и по наименьшей, и по наибольшей ширине узкая, с резким профилем по линии фронтотемпоральных точек. Ее хорда и дуга средние, а высота изгиба небольшая. Теменная дуга и хорда короткие. Что касается затылочной кости, то она широкая, с дугой и хордой средней длины.

Лицо узкое по значению скулового диаметра и среднеширокое по значению верхней ширины. По верхней высоте лицо высокое и резко профилированное по назомалярному углу. Альвеолярная дуга и небо средней ширины и длины. Нос высокий и широкий по абсолютным размерам, а по указателю узкий (лепторинный), с антропинной формой нижнего края грушевидного отверстия. Носовые кости широкие.

Череп из погребения 4 кургана 66 могильника Царев, раскопанного Е.П. Мыськовым (1989), принадлежал юноше в возрасте 1618 лет (см. строку 6 табл. 1). Его мозговая коробка с сильной посмертной деформацией, поэтому определены лишь размеры лобной кости, дуга и хорда теменной кости. Лицевой скелет хорошей сохранности, и почти все признаки были измерены. По вертикальной норме череп, скорее всего, эллипсоидной формы, со слабо выраженным рельефом, видимо, из-за юного возраста погребенного. Его лобная кость средней ширины по 9-му размеру и большой ширины по 10-му. По углу поперечного изгиба кость хорошо профилирована. Как ее дуга и хорда, так и дуга и хорда теменной кости длинные.

Лицевой скелет по верхней ширине средний, а по средней - узкий. Его высота большая, а горизонтальный профиль уплощенный на верхнем уровне и резкий на среднем. Аль- 
веолярная дуга средней ширины, а небо длинное и узкое. Нос средней высоты и узкий как по абсолютным размерам, так и по указателю, с формой нижнего края грушевидного отверстия sulcus; передненосовая ость выражена выше среднего. Глазница узкая и средневысокая по абсолютной высоте и высокая по указателю (гипсиконхная). Переносье по дакриальным размерам среднеширокое и средневысокое, носовые кости средней ширины и высокие. Клыковая ямка глубокая.

Череп из погребения 9 кургана 2 могильника Водянский, раскопанного В.И. Мамонтовым в 1988 году, принадлежал мужчине старше 50 лет (строка 7 табл. 1) [Мамонтов, 2011 , с. 161, 162]. Его мозговая коробка средних размеров по всем трем тотальным размерам. По черепному указателю - суббрахикранный, по высотно-продольному-гипсикранный, по высотно-поперечному - метриокранный. Рельеф на черепе очень хорошо развит в области надпереносья и надбровья с хорошо развитыми сосцевидными отростками. Его основание длинное и широкое. Лобная кость широкая, почти прямая, с резким углом поперечного изгиба, короткой дугой и средней длины хордой. Затылочная кость средней ширины с длинной хордой и дугой.

Лицевой скелет низкий и широкий, с резким горизонтальным и ортогнатным вертикальным профилем. Альвеолярная дуга короткая и узкая, небо средней длины и узкое. Нос низкий, широкий и платиринный, с антропинной формой нижнего края грушевидного отверстия и слабо развитой передненосовой остью. Глазница широкая и низкая, а переносье узкое и средней высоты. Носовые кости средней ширины, высокие и умеренно выступающие. Клыковая ямка глубокая.

Курганная группа VIII могильника Первомайский раскапывалась в 1987 г. В.И. Мамонтовым [Мамонтов, 2001]. В могильнике три погребения были атрибутированы как погребения, сооруженные в позднеямную эпоху: мужчины 30-40 лет из погребения 10 кургана 3, мужчины 40-50 лет из погребения 5 кургана 4 и мужчины старше 50 лет из погребения 4 кургана 9.

Череп мужчины из погребения 10 кургана 3 длинный, узкий, высокий от базион - брегма и низкий по ушной высоте (строка 8 табл. 1).
По указателям череп резко долихокранный, ортокранный и акрокранный. Череп достаточно массивный, эллипсоидной формы, с хорошо развитым надпереносьем, надбровными дугами, наружным затылочным бугром и сосцевидными отростками. Основание черепа длинное и узкое. Лобная кость и по наименьшей, и по наибольшей ширине узкая, с резким профилем по линии фронтотемпоральных точек и сильно наклонная по линии назион - метопион. Ее хорда и дуга средние, а высота изгиба небольшая. Теменная дуга и хорда короткие. Что касается затылочной кости, то она узкая, с длинной дугой и средней длины хордой.

Лицо узкое по значению скулового диаметра и по значению верхней ширины и среднеширокое по значению средней ширины лица. Его высота большая, горизонтальная профилировка клиногнатная, а вертикальная - ортогнатная. Альвеолярная дуга и небо узкие, нос высокий, узкий и по абсолютным размерам, и по указателю (лепторинный), с антропинной формой нижнего края грушевидного отверстия и хорошо развитой передненосовой остью. Глазница среднеширокая и высокая, а по указателю мезоконхная. Переносье широкое, а носовые кости среднеширокие. Клыковая ямка глубокая.

Второй мужской череп этой курганной группы из погребения 5 кургана 4 был плохой сохранности (см. строку 9 табл. 1). Мозговая коробка с сильной посмертной деформацией, и тотальные размеры черепной коробки не удалось измерить. Несмотря на это, хорошо видно, что череп относится к долихокранным типам. Лобная кость на этом черепе по 9-му размеру средней ширины, а по 10-му - широкая. Угол поперечного изгиба с тенденцией к уплощению. Лобная и теменная хорда и дуга большие, как и высота изгиба лба.

Лицо широкое по значениям верхней и средней ширины и средневысокое. Его горизонтальная профилировка резкая на обоих уровнях. Альвеолярная дуга средней длины и широкая, а небо средней ширины. Что касается носа, то он высокий и широкий по абсолютным размерам, но средней ширины (мезоринный) по указателю. Глазница у него мезоморфного строения по абсолютным размерам и высокая по указателю (гипсиконхная). Переносье по значению максилофронтальной ширины, а так- 
же носовые кости относительно широкие. Глубина клыковой ямки - средняя.

Третий череп курганной группы VIII могильника Первомайский из погребения 4 кургана 9 относительно хорошей сохранности, удалось отреставрировать его почти весь (см. строку 10 табл. 1). Сразу следует отметить облитерацию черепных швов, которая в совокупности со степенью стертости зубов позволила определить возраст умершего: старше 50 лет. Его мозговая коробка длинная и узкая, по черепному указателю долихокранная. Высота была измерена от порион - порион, и она оказалась в пределах больших величин. Лобная кость на этом черепе по 9-му размеру широкая, а по 10-му - узкая. Ее угол поперечного изгиба резкий, а угол от назион метопион с тенденцией к покатости. Лобная, теменная и затылочная хорды и дуги средней длины. Высота изгиба лба средняя.

Лицо очень узкое и высокое, с клиногнатной горизонтальной и мезогнатной вертикальной профилировками. Альвеолярная дуга короткая и среднеширокая, небо узкое. Что касается носа, то он средневысокий и узкий как по абсолютным размерам, так и по относительным (лепторинный). Глазница у него широкая и средневысокая (мезоконхная). Носовые кости среднеширокие и очень высокие, резко выступающие к линии профиля. Глубина клыковой ямки мелкая.

Кроме мужского костяка, в этом погребении был обнаружен череп молодой женщины без нижней челюсти. На ее лобной кости, в области венечного шва, было зафиксировано трепанационное отверстие овальной формы [Мамонтов, 2001, с. 187]. К сожалению, для изучения этот череп был нам не доступен.

Еще три черепа, два мужских и один женский, были получены при раскопках могильника Новый Рогачик в 1979 году. Автор раскопок и публикации - В.И. Мамонтов (1998).

Черепа были получены при раскопках кургана 3 (погребения 2 и 5) и кургана 7 (погребение 9).

Череп из погребения 2 кургана 3 принадлежал мужчине, которому на момент смерти было около 30-40 лет (строка 11 табл. 1). Его мозговая коробка очень массивная, длинная, широкая и высокая от порион - порион, с ме- зокранным указателем. Вертикальный профиль мозговой коробки ближе к сфеноидной форме, с хорошо выраженным рельефом в области переносья, надбровных дуг, сосцевидных отростков, наружного затылочного бугpa. Основание черепа средней ширины, а лобная кость широкая по обоим признакам, резко профилированная по углу поперечного изгиба и покатая по углу от назион - метопион. Ее хорда и дуга средней длины, а высота изгиба небольшая. Что касается теменной кости, то ее хорда длинная, а дуга средней длины. Затылочная кость широкая, с длинной хордой и дугой.

Лицевой скелет широкий и высокий с резкой горизонтальной профилировкой на обоих уровнях и ортогнатной вертикальной профилировкой. Альвеолярная дуга широкая, а носширокий и высокий с платиринной пропорцией. Глазница широкая и низкая, с хамэконхной пропорцией. Переносье, судя по значениям максилофронтальной ширины, широкое.

Череп из погребения 5 кургана 3 , скорее всего, принадлежал женщине, которой в момент смерти было около 35-45 лет (рис. 1,2; строка 12 табл. 1). Череп относительно хорошей сохранности, и после реставрационных работ удалось снять почти все признаки. Череп укладывается в категорию среднедлинных, широких, брахикранных, со сфоноидной формой черепа сверху. Его ушная высота большая, а рельеф в области надпереносья, надбровных дуг, наружного затылочного бугра и сосцевидных отростков выражен выше среднего. Основание черепа широкое, как и его лобная кость, по обоим широтным признакам. Профилировка лба по углу поперечного изгиба резкая, а по углу профиля назион - метопион сильно покатая. Лобная хорда и дуга короткие, а теменная хорда и дуга средней длины. Что касается затылочной кости, то она широкая с длинной хордой и дугой.

Лицо широкое по всем трем широтным

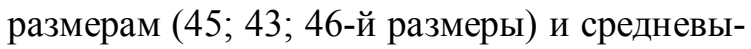
сокое, с резкой горизонтальной профилировкой по назомалярному углу и несколько ослабленной по зигомаксилярному углу. Вертикальный профиль лица ортогнатный. Нос средневысокий и узкий по абсолютным размерам и мезоринный по указателю. Глазница широкая, средневысокая как по 52-му размеру, так и по ука- 
зателю (мезоконхная). Переносье и носовые кости, судя по значениям максилофрональной и симотической ширины, очень широкие. Из краниоскопических признаков на черепе зафиксирован случай метопизма, а также наличие одного надглазничного отверстия.

Мужской череп из погребения 9 кургана 7 могильника Новый Рогачик был представлен хорошей сохранности мозговой коробкой и неполным лицевым скелетом (см. строку 13 табл. 1). Его морфологическая характеристика укладывается в категорию длинных, узких и высокосводчатых черепов с долихокранным, гипсикранным и акрокранным указателями. Основание черепа длинное и широкое, лобная кость широкая по обоим широтным признакам с резким углом в месте перегиба. Дуга лобной кости длинная, а хорда средней длины. Теменная хорда очень короткая, а дуга средней длины. Что касается затылочной кости, то она широкая с дугой средней длины, а хордой короткой.

Лицо широкое, высокое и плоское на уровне глазниц. Его альвеолярная дуга средняя, высота и ширина носа большая по абсолютным размерам и мезоринная по указателю. Нижний край грушевидного отверстия антропинной формы, со среднеразвитой передненосовой остью. Глазница средней высоты, клыковая ямка средней глубины.

Могильник Орешкин I раскапывался в 1989 году экспедицией Волгоградского государственного университета [Дьяченко, 1989]. В погребении 1 кургана 2 был погребен молодой мужчина в возрасте 25-30 лет (рис. 1,3; строка 14 табл. 1). Его череп характеризуется средними размерами продольного и поперечного диаметров, мезокранной и сфеноидной формой. Высота свода по значению ушной высоты большая. Рельеф на черепе хорошо развит. Лобная кость узкая как по значению наименьшей ширины, так и по значению наибольшей ширины. Угол поперечного изгиба лба большой, а угол назион - метопион характеризует лоб как покатый. Лобная дуга короткая, а хорда средней длины. Теменная хорда средней длины, а дуга длинная. У затылочной кости ширина между точками астерион большая, хорда средней длины, а дуга длинная.

Лицо широкое и высокое, слегка уплощенное на уровне глазниц и ортогнатное в вер- тикальной плоскости. Нос средней высоты, большой ширины и платиринный по указателю. Нижний край грушевидного отверстия антропинной формы, а передненосовая ость развита средне. Глазница широкая и средневысокая. Переносье широкое и средневысокое, а носовые кости узкие и низкие, резко выступающие. Клыковая ямка средней глубины.

Череп из погребения 5 кургана 2 могильника Горный (раскопки В.И. Мамонтова 1989 г.) принадлежал мужчине 30-40 лет (рис. 1,4; строка 15 табл. 1). Его мозговая коробка по абсолютным размерам длинная, среднеширокая и высокая, по указателям - мезокранная, гипсикранная и акрокранная. Рельеф на черепе очень хорошо развит. Его основание средней длины и широкое, а лобная кость широкая, слегка наклонная, с резким углом поперечного изгиба, длинной дугой и хордой. Затылочная кость широкая с длинной хордой и средней длины дугой.

Лицо средневысокое и очень широкое, с резким горизонтальным и мезогнатным вертикальным профилем. Альвеолярная дуга длинная и широкая, а небо средней длины и ширины. Нос низкий, узкий и мезоринный, с антропинной формой нижнего края грушевидного отверстия и очень длинной передненосовой остью. Глазница широкая и низкая, а переносье и носовые кости широкие и высокие. Угол выступания носа большой, а клыковая ямка средней глубины.

Еще один мужской череп, из погребения 6 кургана 29 могильника Перегрузное I, был нами опубликован в коллективной монографии [Балабанова и др., 2014, с. 234].

Мозговой отдел женского черепа из погребения 11 кургана 4 могильника Усть-Погожье (раскопки 1986 г. В.И. Мамонтова) был с сильной посмертной деформацией (см. строку 16 табл. 1). Череп с широким лбом, у которого резкий угол поперечного изгиба. У лобной и затылочной костей хорда и дуга длинные, а у теменной - средней длины.

Лицо низкое, в верхней части широкое и резко профилированное. Альвеолярная дуга средней длины и ширины, нос средней высоты и широкий (платиринный). Глазница низкая и узкая, а переносье очень широкое и высокое. Носовые кости среднеширокие и низкие, слабо выступающие. 
Индивидуальная характеристика мужских черепов из погребений позднеямного хронологического пласта показывает, что большинство из них долихо-мезокранного типа, с хорошо развитым рельефом. В вертикальной плоскости преобладают эллипсоидные и овоидные формы. Лобная кость по ширине варьируется от узких форм до очень широких, но ее угол поперечного изгиба почти на всех черепах резкий, а угол профиля назион - метопион чаще покатый. По строению лицевого отдела преобладают высоколицые формы с более-менее выраженной горизонтальной и мезогнатной вертикальной профилировками. Отдельные части лицевого отдела демонстрируют большие широтные размеры (альвеолярная дуга; нос, глазница; переносье) и сильно выступающие носовые кости (табл. 2).

Женские черепа по тотальным характеристикам относительно крупнее мужских, шире в поперечном диаметре мозгового отдела и размерах лицевого, больше по высоте свода (табл. 3). В этом отношении отличаются черепа из погребения 5 кургана 3 могильника Новый Рогачик и череп из погребения 9 кургана 1 могильника Майоровский. Они характеризуются средними размерами продольного диаметра, большими - поперечного и брахикранным черепным указателем. Нужно сказать, что данная выборка, несмотря на ряд общих черт, не выглядит однородной.

Морфологическое отличие и сходство населения ямной культуры, оставившего могильники Волгоградской области, и населения других культурных образований демонстрируют результаты межгруппового канонического анализа. В него включены краниологические материалы только по мужским сериям, так как женская серия малочисленная. Всего анализировались 24 серии от эпохи энеолита до средней бронзы (табл. 4). Рассматривались первые два канонических вектора, на которые приходится более 61,0 \% межгрупповой изменчивости. Первый канонический вектор, являясь, по сути, «фактором размера», отражает межгрупповую вариабельность серий только по поперечному диаметру. Максимальные значения по ширине черепа имеют серии «ямников» из могильников, раскопанных по трассе канала Волга - Чограй, раннекатакомбная серия Калмыкии, «ямники» могильника Кривая Лука и др. Обе серии из могильников Волгоградской области имеют отрицательные значения по этому вектору, тем самым относясь к группе с относительно узкой черепной коробкой.

Второй канонический вектор разграничивает межгрупповую совокупность по двум признакам: симотический указатель (отрицательная связь) и угол выступания носа (положительная связь). Сочетание сильно выступающего носа при относительно низкой высоте носовых остей наблюдается в следующих группах: «ямники» (группа из могильников Поволжской степи), поздняя группа «ямников» (из могильников Волгоградской области), суммарная группа майкопской культуры. Альтернативное сочетание признаков демонстрируют хвалынская энеолитическая группа и катакомбные группы: новочеркасская и суммарная группа из могильников Волгоградской области. Положение групп в плоскостях первого и второго канонических векторов, а также проведенный кластерный анализ на основе расстояний Махаланобиса демонстрируют морфологическое сходство исследуемых групп, которое можно интерпретировать как родство.

Итак, мы сопоставили 24 мужские краниологические выборки между собой с помощью кластеризации расстояний Махаланобиса (взвешенный парно-групповой способ) и канонического анализа по набору 14 краниологических признаков $(1,8,9,17,45,48,55,54$, 51, 52, 77, <zm', SS:SC), 75-1). В результате кластеризации расстояний Махаланобиса (рис. 2) выделяются три основные совокупности краниологических серий, имеющие культурно-хронологическую локализацию. Вопервых, обособляется выборка черепов майкопской культуры, морфологическую специфику этой группы определяет преобладание в ней южного антропологического типа с краниологическим комплексом, характеризующим средиземноморский тип [Казарницкий, 2012, c. 36]. К данной совокупности присоединяется группа черепов из поздней группы «ямников» Волгоградской области, которые имеют сходство с майкопской группой по сочетанию «относительно низкие носовые кости при большом угле выступания носа».

Особую группу образовали серии ямной культуры Калмыкии и Астраханской области (чограйская, группа могильников по трассе 
канала Волга - Чограй, суммарная серия из могильников Калмыкии и группа из могильника Кривая Лука), серия из погребений ямнокатакомбного времени Калмыкии и раннекатакомбная группа Калмыкии. Эти серии отличаются от всей остальной совокупности широкой черепной коробкой.

Серии «ямников» северной локализации также обособились. Это группы, опубликованные А.А. Хохловым [Хохлов, 1999; Хохлов и др., 2016], серии из могильников Волго-Уральской лесостепи, из могильников Поволжской степи и из могильников Самарского Заволжья и Оренбуржья (ранняя группа) [Хохлов, 1999].

Ранняя группа «ямников» Волгоградской области оказалась в связке с группой поздних «ямников» из могильников Самарского Заволжья и Оренбуржья, с сериями катакомбной культуры восточно-маныческой группы (южные районы Калмыкии) [Казарницкий, 2012].

Таким образом, на основании результатов сравнения исследуемых групп ямной культуры из могильников Волгоградской об- ласти на фоне серий других культур энеолита - бронзы можем сформулировать следующие положения:

1. Население «ямной» культуры раннебронзового века было неоднородным. В его морфологическом облике прослеживаются в основном европеоидный гиперморфный и мезоморфный компоненты. Больше половины черепов представлены широколицым европеоидным вариантом.

2. Исходя из общих результатов межгруппового анализа, группы ямного населения Волгоградской области имеют близкие аналогии с синхронным ямным населением Самарского Заволжья и Оренбуржья и, возможно, с населением майкопской культуры.

3. Краниологическая выборка ямного времени из могильников Волгоградской области по своим морфологическим характеристикам отличается от синхронных групп Калмыкии и Астраханского правобережья и тяготеет к группам из территории Самарского Заволжья и Оренбуржья. 


\section{ИЛЛЮСТРАЦИИ}
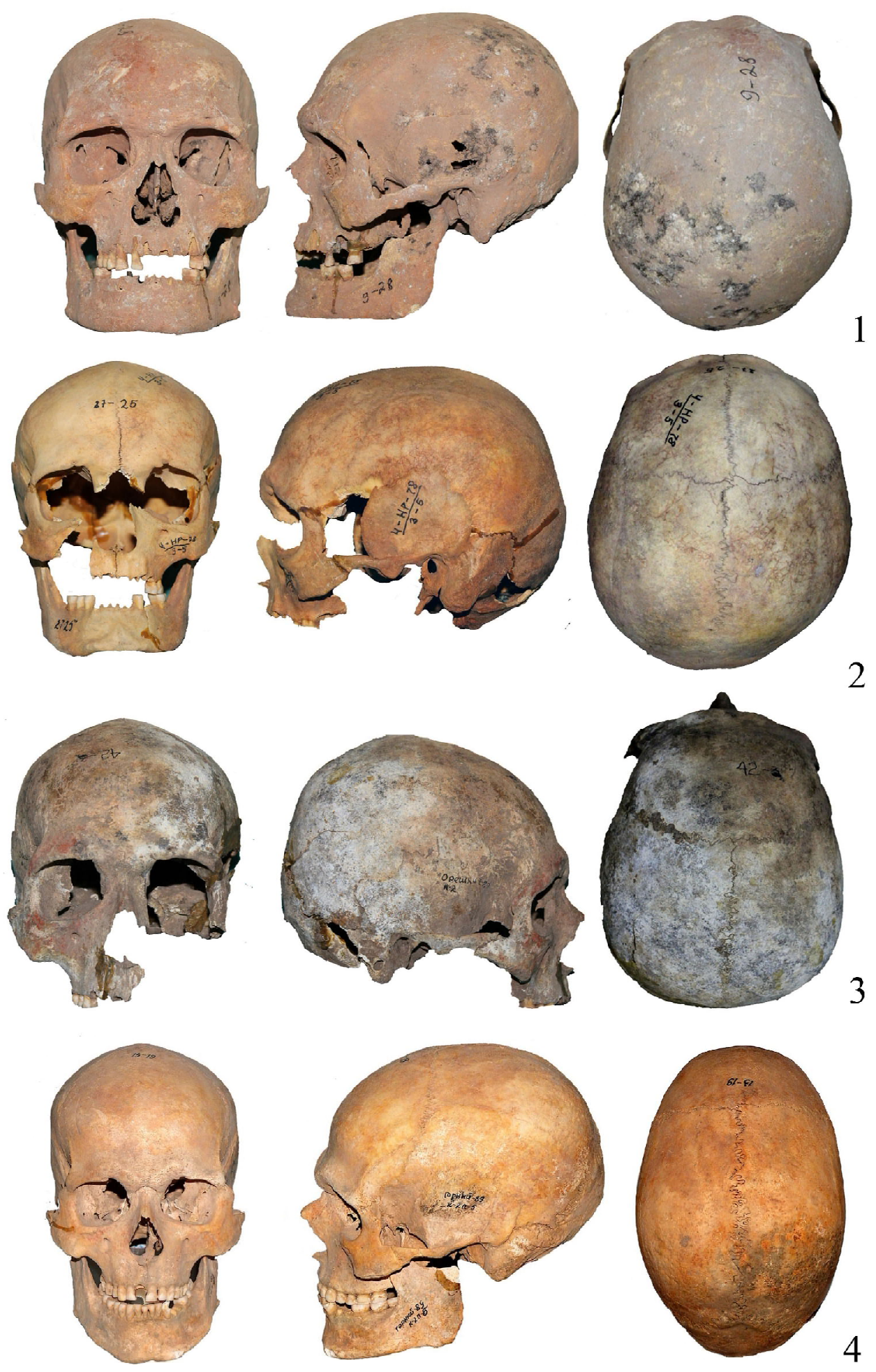

Рис. 1. Морфологический тип ямников Волгоградской области:

1 - череп мужчины 35-40 лет из погребения 5 кургана 14 могильника Писаревка II; 2 - череп женщины 35-45 лет из погребения 5 кургана 3 могильника Новый Рогачик; 3 - череп мужчины 25-30 лет из погребения 1 кургана 2 могильника Орешкин I; 4 - череп мужчины 30-40 лет из погребения 5 кургана 2 могильника Горный 


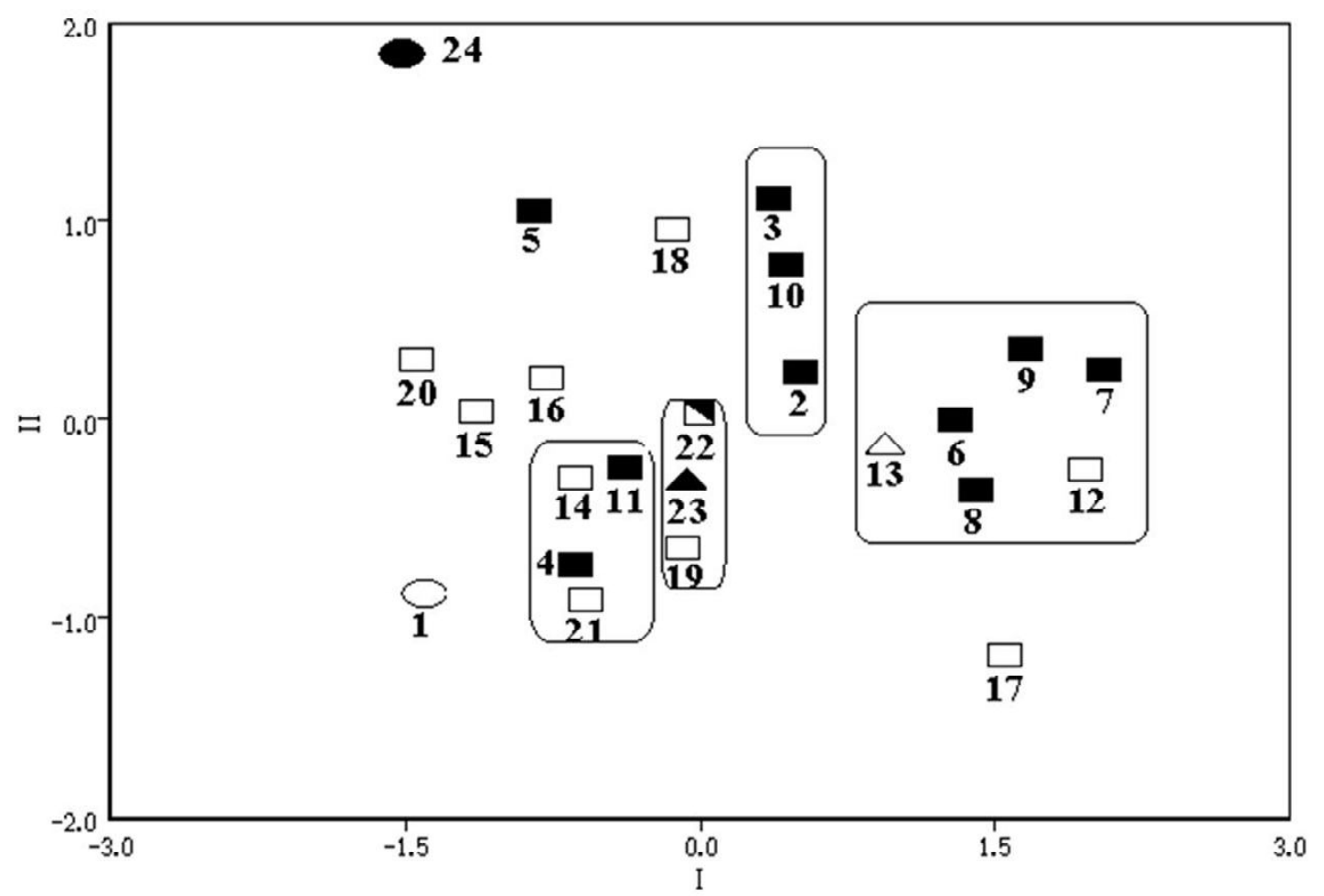

Рис. 2. Результат канонического анализа и кластеризации расстояний Махаланобиса мужских серий эпохи бронзы:

1 - хвальнская культура (энеолит);

ямная культура: 2 - Волго-Уральская лесостепь; 3 - Поволжская степь;

4 - волгоградская группа (ранняя); 5 - волгоградская группа (поздняя); 6 - чограйская группа;

7 - канал Волга - Чограй; 8 - калмыцкая группа (суммар.); 9 - Кривая Лука;

10 - Самарское Заволжье и Оренбуржье (ранняя); 11 - Самарское Заволжье и Оренбуржье (поздняя); катакомбные культуры: 12 - калмыцкая группа (ранние); 13 - калмыцкая группа (ямно-катакомбные погр.); 14 - восточно-маныческая группа (юг); 15 - восточно-маныческая группа (север);

16 - донская группа (левобережье); 17 - новочерскасская группа; 18 - ростовская группа;

19 - ингульская группа; 20 - херсонская группа; 21 - волгоградская группа (суммар.);

22 - полтавкинская культура (суммар.); 23 - новотитаровская культура (курган «Овальный», погр. 35);

24 - майкопская культура 
M.A. Balabanova. On the Anthropology of the Population of the Eneolithic - Early Bronze Age

$\frac{\sqrt{0}}{3}$

\begin{tabular}{|c|c|c|c|c|c|c|c|c|c|c|c|c|c|c|c|c|}
\hline $\begin{array}{r}\text { УПИЛ (угол поперечного } \\
\text { изгиба лба) }\end{array}$ & 泀 & $\begin{array}{l}m \\
m\end{array}$ & ñ & $\stackrel{\infty}{\infty}$ & $\begin{array}{l}\infty \\
0 \\
0 \\
-1 \\
\end{array}$ & $\frac{a}{m}$ & $\stackrel{2}{2}$ & $\begin{array}{l}+ \\
\stackrel{+}{2}\end{array}$ & $\underset{\vec{\Xi}}{\stackrel{\nabla}{\Xi}}$ & $\stackrel{0}{0}$ & $\hat{m}$ & \begin{tabular}{|l|}
$\hat{n}$ \\
$\tilde{n}$ \\
\end{tabular} & $\begin{array}{l}\infty \\
\dot{\sim}^{\infty} \\
-\end{array}$ & \begin{tabular}{l}
0 \\
\multirow{f}{\pm}{} \\
\end{tabular} & $\begin{array}{l}m \\
m \\
m\end{array}$ & $\infty$ \\
\hline $\begin{array}{r}\text { 9:10. Широтный лобный } \\
\text { указатель }\end{array}$ & n & $\begin{array}{l}0 \\
\infty \\
\infty\end{array}$ & n & $\begin{array}{l}a \\
\infty \\
\infty\end{array}$ & $\infty$ & 2 & $\hat{n}$ & $\overbrace{\infty}^{\infty}$ & $\underset{\infty}{\infty}$ & in & $\frac{\pi}{\infty}$ & $\mid \frac{n}{+\infty}$ & $\begin{array}{l}\infty \\
\infty \\
\infty\end{array}$ & זे & $\mid \begin{array}{r}n \\
\infty \\
\infty\end{array}$ & \\
\hline $\begin{array}{r}\text { 9:8. Лобно-поперечный } \\
\text { указатель }\end{array}$ & $\frac{n}{2}$ & $\infty$ & ชิ & $\infty$ & $\begin{array}{l}0 \\
2 \\
r\end{array}$ & & $\begin{array}{l}0 \\
2 \\
r\end{array}$ & ชู & & $\stackrel{2}{2}$ & $\vec{b}$ & $\begin{array}{l}0 \\
0 \\
0 \\
1\end{array}$ & 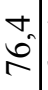 & $\hat{\sigma}$ & ì & \\
\hline 9. Наименьшая ширина лба & 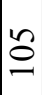 & ñ & å & $\hat{a}$ & ñ & ボ & - & $\infty$ & $\curvearrowleft$ & 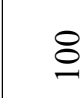 & $\tilde{\varrho}$ & $\overline{\underline{ }}$ & $\begin{array}{l}n \\
n \\
0 \\
n\end{array}$ & む゙ & $\stackrel{2}{0}$ & ๑ \\
\hline 20. Ушная высота & $\Xi$ & $\overline{\mathrm{I}}$ & & & ปิ & & & בn & & 고 & 긴 & I & $\stackrel{\sim}{\beth}$ & $\Xi$ & $\stackrel{\sim}{\sim}$ & \\
\hline 5. Длина основания черепа & $\stackrel{2}{0}$ & $\stackrel{\infty}{=}$ & & & $\stackrel{m}{m}$ & & $\stackrel{n}{2}$ & $\stackrel{ \pm}{0}$ & & & & & $\cong$ & & ชิ & \\
\hline $\begin{array}{r}\text { М3. Условный } \\
\text { трансверсальный объем }\end{array}$ & $\begin{array}{l}\infty \\
\sim \\
\infty\end{array}$ & $\frac{\pi}{\tilde{n}}$ & & & $\begin{array}{l}n \\
\infty \\
\infty \\
\infty\end{array}$ & & $\begin{array}{c}0 \\
0 \\
0 \\
-\end{array}$ & $\stackrel{\sigma}{\approx}$ & & & & & $\begin{array}{l}\infty \\
0 \\
2 \\
\simeq\end{array}$ & & 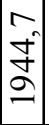 & \\
\hline $\begin{array}{r}\text { М2. Условное } \\
\text { трансверсальное сечение }\end{array}$ & $\frac{\mathrm{N}}{\mathrm{N}}$ & ì & $\stackrel{\sim}{\sim}$ & 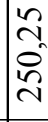 & ָั & & 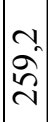 & $\stackrel{v_{n}}{\sim}$ & & ช̊ & $\mid \begin{array}{c}0 \\
\infty \\
\infty \\
N\end{array}$ & $\mid$\begin{tabular}{l}
$\infty$ \\
$\infty$ \\
\multirow{2}{\infty}{}
\end{tabular} & 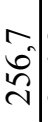 & 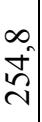 & $\mid \begin{array}{c}\nabla_{+} \\
0 \\
0 \\
\sim\end{array}$ & \\
\hline $\begin{array}{r}\text { ОРВ (общеростовая } \\
\text { величина) }\end{array}$ & $\frac{\text { a }}{\sqrt{2}}$ & $\begin{array}{l}0 \\
i \\
\infty \\
\text { in }\end{array}$ & & & \begin{tabular}{l}
0 \\
6 \\
\multirow{2}{N}{}
\end{tabular} & & 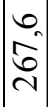 & $\begin{array}{r}\text { r } \\
\infty \\
0\end{array}$ & & & & & $\begin{array}{l}0 \\
\stackrel{n}{2} \\
\stackrel{n}{2}\end{array}$ & & $\begin{array}{l}2 \\
2 \\
2 \\
2\end{array}$ & \\
\hline $\begin{array}{r}\text { 17/8. Высотно-поперечный } \\
\text { указатель }\end{array}$ & ล் & 官 & & & $\hat{\sigma}$ & & $\begin{array}{l}\nabla_{n} \\
\dot{A}\end{array}$ & $\overbrace{0}^{0}$ & & & & & $\begin{array}{c}\nabla_{0} \\
\stackrel{0}{\sigma}\end{array}$ & & \begin{tabular}{l|}
$\nabla_{+}$ \\
\\
0 \\
\end{tabular} & \\
\hline $\begin{array}{r}17 / 1 . \text { Высотно-продольный } \\
\text { указатель }\end{array}$ & $\stackrel{2}{r}$ & $\stackrel{\sim}{r}$ & & & $\stackrel{\nabla}{\sim}$ & & $\begin{array}{l}0 \\
n \\
n\end{array}$ & n & & & & & $\begin{array}{c}m \\
n\end{array}$ & & $\begin{array}{l}a \\
\infty \\
\infty\end{array}$ & \\
\hline $\begin{array}{r}\text { 17. Высотный диаметр } \\
(\mathrm{Ba}-\mathrm{B})\end{array}$ & $\stackrel{m}{m}$ & $\bar{n}$ & & & $\underset{J}{ \pm}$ & & $\begin{array}{l}0 \\
2\end{array}$ & $\underline{m}$ & & & & & $\stackrel{\circ}{ \pm}$ & & $\begin{array}{l}0 \\
\pm\end{array}$ & \\
\hline 8/1. Черепной указатель & 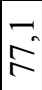 & $\infty$ & $\stackrel{+}{\sim}$ & 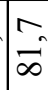 & $\begin{array}{l}m \\
\vec{b}\end{array}$ & & $\infty$ & $\stackrel{\nabla^{\prime}}{\stackrel{R}{ }}$ & & 吕 & $\frac{N}{2}$ & $\mid \begin{array}{c}n \\
\vdots \\
\infty\end{array}$ & 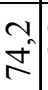 & हैं & $\begin{array}{l}\infty \\
N \\
N\end{array}$ & \\
\hline 2. Поперечный диаметр & $\stackrel{n}{ \pm}$ & $\stackrel{\infty}{m}$ & $\stackrel{\circ}{n}$ & $\stackrel{m}{ \pm}$ & $\stackrel{\infty}{\simeq}$ & & 寻 & $\stackrel{m}{m}$ & & $\stackrel{\infty}{\sim}$ & 守 & $\stackrel{\mathscr{P}}{\Xi}$ & $\begin{array}{l}\infty \\
2\end{array}$ & $\stackrel{\circ}{ \pm}$ & $\stackrel{ \pm}{ \pm}$ & \\
\hline 1. Продольный диаметр & $\infty$ & $\approx$ & $\underset{\infty}{\infty}$ & $\stackrel{n}{2}$ & & & $\stackrel{\infty}{\infty}$ & $\infty$ & & $\stackrel{\bullet}{\infty}$ & $\tilde{\Omega}$ & 妾 & $\begin{array}{l}\circ \\
\infty\end{array}$ & $\underset{\infty}{\infty}$ & $\begin{array}{l}\infty \\
\infty\end{array}$ & \\
\hline , лет & $\begin{array}{l}0 \\
\text { Y } \\
\text { n } \\
\text { n }\end{array}$ & $\begin{array}{l}0 \\
\stackrel{\sim}{1} \\
\stackrel{8}{+}\end{array}$ & กิ & $\underset{l}{\infty}$ & $\begin{array}{l}0 \\
n \\
0 \\
+\end{array}$ & $\frac{\infty}{b}$ & $\begin{array}{c}\stackrel{0}{ } \\
\dot{0}\end{array}$ & $\begin{array}{l}\text { o } \\
\text { † } \\
\text { ’ }\end{array}$ & $\begin{array}{l}0 \\
\stackrel{1}{1} \\
\stackrel{+}{+}\end{array}$ & $\begin{array}{l}\stackrel{0}{n} \\
\dot{0}\end{array}$ & $\begin{array}{l}0 \\
\dot{+} \\
0 \\
\text { m }\end{array}$ & \begin{tabular}{|l|}
$n$ \\
$\stackrel{y}{ }$ \\
$n$ \\
$m$
\end{tabular} & $\begin{array}{l}n \\
\dot{y} \\
n \\
n\end{array}$ & 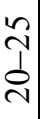 & \begin{tabular}{|l|} 
\\
\\
\\
f \\
\end{tabular} & $\begin{array}{l}\stackrel{\sim}{1} \\
\infty \\
-\end{array}$ \\
\hline Пол & $\Sigma$ & $\Sigma$ & $\Sigma$ & 条 & $\Sigma$ & $\Sigma$ & $\Sigma$ & $\Sigma$ & $\Sigma$ & $\Sigma$ & $\Sigma$ & 资 & $\Sigma$ & $\Sigma$ & $\Sigma$ & 资 \\
\hline № погребения & in & $\infty$ & $\bar{a}$ & $\frac{N}{\sigma}$ & - & $\nabla$ & $a$ & $ㅇ$ & in & $\nabla$ & $N$ & $n$ & $a$ & - & $n$ & $=$ \\
\hline № кургана & $\Xi$ & a & 一 & - & 6 & 6 & $N$ & $m$ & t & $a$ & $m$ & $m$ & r & $N$ & $N$ & $\theta$ \\
\hline Могильник & 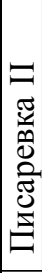 & 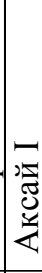 & 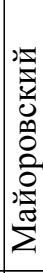 & 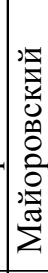 & $\begin{array}{l}0 \\
0 \\
0 \\
0 \\
0 \\
0 \\
0 \\
0 \\
0\end{array}$ & 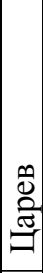 & 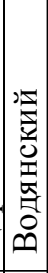 & 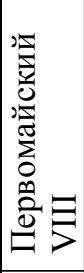 & 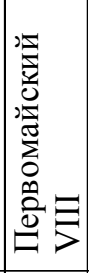 & 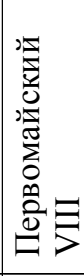 & 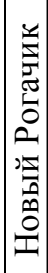 & 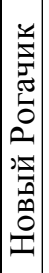 & 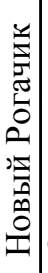 & 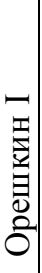 & 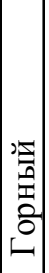 & $\begin{array}{l}0 \\
0 \\
0 \\
0 \\
0 \\
0 \\
1 \\
0 \\
0 \\
0\end{array}$ \\
\hline № п/п & 一 & $\sim$ & $m$ & $\nabla$ & in & 0 & $r$ & $\infty$ & a & 으 & $=$ & $\simeq$ & 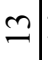 & \pm & $n$ & $\underline{0}$ \\
\hline
\end{tabular}


М.А. Балабанова. К антропологии населения энеолита - ранней бронзы

\begin{tabular}{|c|c|c|c|c|c|c|c|c|c|c|c|c|c|c|c|c|}
\hline $\begin{array}{r}\text { 45:8. Поперечный } \\
\text { краниофациальный } \\
\text { указатель }\end{array}$ & 毒 & $\stackrel{0}{0}$ & & & 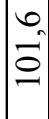 & & ñ & $\hat{a}$ & & & $\frac{a}{a}$ & $\begin{array}{c}0 \\
\hat{n}\end{array}$ & $\begin{array}{l}0 \\
\text { m. } \\
\hat{0}\end{array}$ & $\overbrace{}^{2}$ & $\widetilde{0}$ & \\
\hline 45. Скуловой диаметр & $\bar{n}$ & $\begin{array}{l}\infty \\
m \\
m\end{array}$ & & & $\stackrel{\circ}{2}$ & & $\underline{m}$ & $\stackrel{0}{m}$ & & $\cong$ & $\hat{n}$ & $m$ & $\stackrel{\overbrace{}}{ \pm}$ & $\stackrel{0}{ \pm}$ & $\underset{\Xi}{\Xi}$ & \\
\hline Угол изгиба затылка & $\stackrel{\sim}{\sim}$ & $\begin{array}{l}\nabla_{0} \\
\stackrel{2}{c}\end{array}$ & & & $\begin{array}{l}\sigma_{0} \\
\stackrel{2}{\beth}\end{array}$ & & 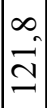 & $\cong$ & & ปิ & $\stackrel{\Xi}{\beth}$ & $\begin{array}{c}\hat{\infty} \\
\stackrel{\infty}{c} \\
-\end{array}$ & $\begin{array}{l}a \\
\infty \\
\text { ch }\end{array}$ & حู & $\stackrel{\infty}{\stackrel{N}{N}}$ & $\begin{array}{l}\infty \\
\infty \\
n \\
n\end{array}$ \\
\hline Указатель изгиба затылка & $\vec{\infty}$ & $\begin{array}{l}\hat{\sigma}^{\circ} \\
\text { N }\end{array}$ & & & $\begin{array}{l}\infty \\
\curvearrowright \\
\curvearrowright\end{array}$ & & $\begin{array}{l}\infty \\
\hat{N} \\
\end{array}$ & $\vec{m}$ & & $\stackrel{\sim}{\sim}$ & 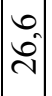 & \begin{tabular}{l}
0 \\
\multirow{2}{*}{}
\end{tabular} & ๙ે & 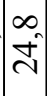 & $\underset{\sim}{\sim}$ & $\stackrel{m}{\overbrace{}^{2}}$ \\
\hline Высота изгиба затылка & $\widehat{\sim}$ & $\begin{array}{l}n \\
\infty \\
\sim\end{array}$ & & & $n$ & & $\begin{array}{l}\infty \\
\hat{n} \\
\sim\end{array}$ & $m$ & & $\stackrel{\bullet}{\sim}$ & 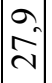 & $\begin{array}{l}n \\
\stackrel{n}{N}\end{array}$ & ป & $\begin{array}{l}\infty \\
\sim \\
\sim\end{array}$ & $\stackrel{\infty}{\curvearrowright}$ & 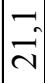 \\
\hline Угол изгиба лба & $\stackrel{+}{\sim}$ & $\begin{array}{l}2 \\
6 \\
n \\
-\end{array}$ & $\stackrel{\infty}{\infty}$ & $\begin{array}{l}\infty \\
\\
\end{array}$ & $\begin{array}{l}0 \\
0 \\
2 \\
-1\end{array}$ & & $\underline{m}$ & $\begin{array}{l}\infty \\
\tilde{m} \\
\tilde{n}\end{array}$ & $\overrightarrow{\mathrm{a}}$ & $\begin{array}{l}\vec{n} \\
\tilde{m}\end{array}$ & $\begin{array}{l}\infty \\
\infty \\
\infty \\
-1 \\
\end{array}$ & $\begin{array}{l}\nabla_{n} \\
\tilde{n} \\
\tilde{=}\end{array}$ & 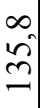 & $\begin{array}{l}\infty \\
\infty \\
\infty \\
-\end{array}$ & $\stackrel{\sim}{\sim}$ & $\begin{array}{l}n \\
\mathfrak{m} \\
\beth\end{array}$ \\
\hline Указатель изгиба лба & $\stackrel{\sim}{\sim}$ & $\vec{\sim}$ & $\begin{array}{l}\sigma^{\prime} \\
\stackrel{\sim}{2}\end{array}$ & in & $\begin{array}{l}+ \\
\sigma_{+}\end{array}$ & & â. & $\hat{n}^{2}$ & 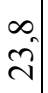 & $\vec{a}$ & $\begin{array}{l}\infty \\
\infty \\
-\end{array} \mid$ & $\stackrel{n}{\infty}$ & $\stackrel{2}{2}$ & $\infty$ & N & $\underbrace{n}_{0}$ \\
\hline 26. Высота изгиба лба & $\stackrel{4}{4}$ & 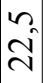 & is & n & $\frac{n}{n}$ & & $\left|\begin{array}{l}n \\
\stackrel{d}{d}\end{array}\right|$ & 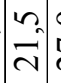 & $\frac{a}{2}$ & $\left|\begin{array}{l}n \\
\stackrel{d}{d}\end{array}\right|$ & $\bar{\sim}$ & $\frac{n}{2}$ & $\tilde{n}^{n}$ & 完 & & ำ \\
\hline $\begin{array}{l}\text { Индекс кривизны } \\
\text { затылочной кости }\end{array}$ & $\left|\begin{array}{l}\infty \\
i \\
\infty\end{array}\right|$ & $\begin{array}{l}\infty \\
+ \\
\infty\end{array}$ & & & $\begin{array}{l}0 \\
+ \\
\infty\end{array}$ & & $\left|\begin{array}{c}m \\
m \\
\infty\end{array}\right|$ & $\mid \begin{array}{l}0 \\
2 \\
2\end{array}$ & & $\mid \begin{array}{c}n \\
\infty \\
\infty\end{array}$ & m. & $\left|\begin{array}{c}r \\
\infty \\
\infty\end{array}\right|$ & $\frac{\sigma_{0}}{\infty}$ & $\infty$ & $\frac{0}{\infty}$ & $\left|\begin{array}{l}0 \\
\infty \\
\infty\end{array}\right|$ \\
\hline $\begin{array}{r}\text { Индекс кривизны теменной } \\
\text { кости }\end{array}$ & $\mid \begin{array}{l}2 \\
8\end{array}$ & $\begin{array}{l}0 \\
\infty \\
\infty\end{array}$ & $\begin{array}{l}\infty \\
\infty \\
\infty\end{array}$ & $\begin{array}{l}0 \\
\infty \\
\infty\end{array}$ & $\begin{array}{l}0 \\
\infty \\
\infty\end{array}$ & $\left|\begin{array}{l}0 \\
2 \\
\infty\end{array}\right|$ & $\begin{array}{l}m \\
2 \\
\alpha\end{array} \mid$ & $\mid \begin{array}{l}2 \\
\hat{\infty} \\
\infty\end{array}$ & 2 & $\mid \begin{array}{l}2 \\
\infty \\
\infty\end{array}$ & $\frac{n}{a}$ & $\mid \frac{1}{\infty}$ & $\begin{array}{c}0 \\
\infty \\
\infty\end{array}$ & $\left|\begin{array}{l}0 \\
\infty \\
\infty\end{array}\right|$ & के & $\begin{array}{l}\mathcal{N} \\
0 \\
\infty\end{array}$ \\
\hline $\begin{array}{r}\text { Индекс кривизны лобной } \\
\text { кости }\end{array}$ & $\left|\begin{array}{l}0 \\
\infty \\
\infty\end{array}\right|$ & $\begin{array}{l}0 \\
\infty \\
\infty\end{array}$ & $\begin{array}{l}\sigma_{n} \\
\infty\end{array}$ & $\stackrel{n}{\infty}$ & $\mid \begin{array}{l}\infty \\
\infty \\
\infty\end{array}$ & $\left(\begin{array}{c}n \\
\infty\end{array}\right.$ & $\left|\begin{array}{c}1 \\
\infty \\
\infty\end{array}\right|$ & $\mid \begin{array}{lll}2 & 1 \\
\infty & 1 & 1 \\
\infty & 1 & 0\end{array}$ & 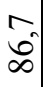 & 2 & $\left|\begin{array}{l}\infty \\
\vdots \\
\infty\end{array}\right|$ & 2 & $\frac{a}{\infty}$ & $\mid \begin{array}{l}2 \\
8 \\
2\end{array}$ & $\frac{\sigma_{0}}{\infty}$ & $\vec{n}$ \\
\hline $\begin{array}{r}28: 27 . \text { Затылочно-теменной } \\
\text { индекс }\end{array}$ & ๘́ & $\begin{array}{l}\nabla_{n} \\
\infty \\
\sigma\end{array}$ & & & ś & & $\begin{array}{l}0 \\
0 \\
0 \\
-1\end{array}$ & $\begin{array}{l}m \\
m \\
0\end{array}$ & & $\begin{array}{l}\sigma \\
\infty \\
\infty\end{array}$ & $\left(\begin{array}{l}n \\
2 \\
\varrho\end{array}\right.$ & $\begin{array}{l}n \\
2 \\
2\end{array}$ & 2 & నू: & $\vec{\infty}$ & 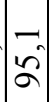 \\
\hline 28. Затылылочная дуга & $\stackrel{0}{=}$ & $\stackrel{n}{\sim}$ & & & $\Xi$ & & 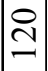 & ป & & 三 & $\stackrel{\sim}{\mathcal{J}}$ & 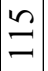 & 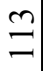 & 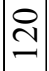 & $\cong$ & $\Xi$ \\
\hline 27. Теменная дуга & ป & ㄱ. & $\stackrel{\overbrace{}}{I}$ & సิ & 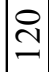 & $\begin{array}{l}0 \\
-1\end{array}$ & 三 & 고 & $\hat{n}$ & 욤 & $\stackrel{\oplus}{-}$ & ㄱ & $\begin{array}{l}0 \\
\text { 工 }\end{array}$ & $\stackrel{m}{m}$ & ปิ & 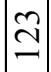 \\
\hline 26. Лобная дуга & ปิ & $\approx$ & 근 & $\stackrel{\infty}{=}$ & $\stackrel{\simeq}{\simeq}$ & $\stackrel{\sim}{\sim}$ & $\stackrel{ \pm}{\beth}$ & $\cong$ & $\stackrel{n}{\sim}$ & 号 & $\stackrel{\text { 工 }}{-1}$ & 三 & $\stackrel{\sim}{\sim}$ & $\stackrel{\Omega}{\simeq}$ & $n$ & 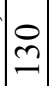 \\
\hline 31. Затылочная хорда & ○ & ○ & & & ๙ & & ○ & 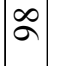 & & ন & $\stackrel{n}{0}$ & $\stackrel{ }{\circ}$ & ส & ○ & 8 & ठ \\
\hline 30. Теменная хорда & 으 & $\stackrel{m}{=}$ & $\stackrel{\infty}{0}$ & $\cong$ & s. & $\vec{ح}$ & 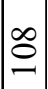 & $\left(\begin{array}{c}n \\
0 \\
n \\
-1\end{array}\right.$ & 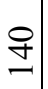 & $\stackrel{0}{=}$ & $\stackrel{2}{=}$ & $\hat{-}$ & ฉ & $\cong$ & $\stackrel{0}{=}$ & ○ \\
\hline 29. Лобная хорда & $\cong$ & $\cong$ & 三 & $\hat{0}$ & $\equiv$ & $\equiv$ & $\stackrel{0}{=}$ & $=$ & $\Xi$ & $\stackrel{m}{=}$ & $\stackrel{N}{=}$ & $\stackrel{\wp}{\varrho}$ & $\stackrel{6}{=}$ & 三 & $\stackrel{N}{\Xi}$ & $\vec{\beth}$ \\
\hline 25. Сагитальная дуга & 同 & $\frac{\pi}{n}$ & & & $\begin{array}{c}\mathcal{V} \\
\text { లn }\end{array}$ & & $\bar{\sigma}$ & $\begin{array}{l}\hat{\sigma} \\
\text { n }\end{array}$ & & 昰 & S্ণ & 离 & $\bar{n}$ & $\frac{0}{m}$ & 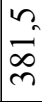 & $\frac{0}{2}$ \\
\hline 12. Ширина затылка & $\Xi$ & & & & 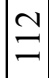 & & $\stackrel{ }{=}$ & Ð & & & 兄 & $\stackrel{\circ}{\circ}$ & $\stackrel{m}{=}$ & 足 & $\stackrel{m}{=}$ & \\
\hline $\begin{array}{r}\text { 11. Ширина основания } \\
\text { черепа }\end{array}$ & 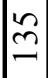 & $\stackrel{\curvearrowright}{\beth}$ & & $\stackrel{\beth}{7}$ & 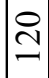 & & $\stackrel{m}{m}$ & 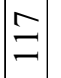 & & $\begin{array}{l}\infty \\
0 \\
=\end{array}$ & $\stackrel{\overbrace{}}{-}$ & $\stackrel{\curvearrowright}{\simeq}$ & $\begin{array}{l}0 \\
-1 \\
=\end{array}$ & $\stackrel{ \pm}{m}$ & $\ddot{m}$ & \\
\hline $\begin{array}{r}\text { 10. Наибольшая ширина } \\
\text { лба }\end{array}$ & 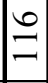 & $\Xi$ & $\stackrel{\overbrace{}}{-}$ & $\stackrel{\sim}{\sim}$ & $\stackrel{0}{=}$ & $\bar{\sim}$ & $\stackrel{m}{m}$ & $\stackrel{2}{1}$ & $\stackrel{\partial}{-}$ & $\Xi$ & 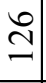 & $\stackrel{\sim}{\sim}$ & $\stackrel{2}{-}$ & 三 & $\stackrel{ \pm}{\beth}$ & \\
\hline № ח/П & - & $N$ & $m$ & $\nabla$ & $n$ & 6 & $r$ & $\infty$ & $a$ & 이 & $二$ & 工 & $\stackrel{m}{=}$ & $\Xi$ & $\because$ & 0 \\
\hline
\end{tabular}


M.A. Balabanova. On the Anthropology of the Population of the Eneolithic - Early Bronze Age

\begin{tabular}{|c|c|c|c|c|c|c|c|c|c|c|c|c|c|c|c|c|}
\hline Назомалярный указатель & $\frac{N}{2}$ & 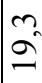 & $\stackrel{\sigma_{n}}{\sim}$ & $\infty$ & กิ & $\ddot{\sigma}$ & $\begin{array}{l}\sigma^{\prime} \\
\infty\end{array}$ & $\begin{array}{l}4 \\
a^{\prime}\end{array}$ & $\begin{array}{l}0 \\
0 \\
\hat{N}\end{array}$ & $\begin{array}{c}0 \\
\text { N } \\
\mid\end{array}$ & ป̂. & $\begin{array}{l}n \\
\text { ה }\end{array}$ & $\begin{array}{l}0 \\
n \\
-\infty\end{array}$ & $\begin{array}{l}\infty \\
\pm \\
=\end{array}$ & & \{ \\
\hline Высота над точкой назион & $\begin{array}{l}n \\
\infty \\
\infty\end{array}$ & in & $=$ & 2 & 이 & $\because$ & $n$ & $\bar{N}$ & ৩ి & 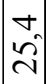 & 䆚 & ๙े & $\begin{array}{l}2 \\
6 \\
-1\end{array}$ & $\infty$ & & $\infty$ \\
\hline Бимолярная ширина & $\begin{array}{l}\infty \\
\hat{0} \\
-\end{array}$ & r & 齐 & \%ั & ลू & I & $\tilde{8}$ & $\begin{array}{l}0 \\
2 \\
2\end{array}$ & 2 & À & $\stackrel{n}{0}$ & 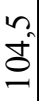 & $\stackrel{+}{0}$ & $\hat{\overbrace{}}$ & $\begin{array}{l}n \\
2 \\
\varrho\end{array}$ & 2 \\
\hline $\begin{array}{r}\text { 52:51. Орбитный указатель } \\
\text { (правый) }\end{array}$ & in & & $\left|\begin{array}{l}2 \\
2 \\
2\end{array}\right|$ & $\infty$ & & $\infty$ & & 定 & $\left|\begin{array}{c}0 \\
\infty \\
\infty\end{array}\right|$ & & & & & & & \\
\hline $\begin{array}{r}\text { 52:51. Орбитный указатель } \\
\text { (левый) }\end{array}$ & in & $\frac{0}{\pi}$ & $\mid \begin{array}{l}2 \\
6 \\
2\end{array}$ & $\cong$ & & $\infty$ & $\stackrel{2}{2}$ & $\frac{\sigma}{\infty}$ & $\begin{array}{l}\sigma_{n} \\
n \\
\infty\end{array} \mid$ & $\mid$ & $\begin{array}{l}m \\
m\end{array}$ & $\begin{array}{l}0 \\
\infty \\
\infty \\
\infty\end{array}$ & & $\frac{n}{2}$ & $\mathfrak{N}^{2}$ & $\left\{\begin{array}{l}0 \\
i \\
\infty\end{array}\right.$ \\
\hline $\begin{array}{r}\text { 52. Высота орбиты } \\
\text { (правая) }\end{array}$ & $m$ & & กี & in & & m & & m & $m$ & & & & & & & \\
\hline 52. Высота орбиты (левая) & m & $\frac{n}{m}$ & m & m & & m & n & m & $n$ & $n$ & $m$ & $m$ & $\mid \begin{array}{l}n \\
\dot{n} \\
m\end{array}$ & $\begin{array}{l}n \\
\tilde{m}\end{array}$ & $\begin{array}{c}m \\
n \\
m\end{array}$ & 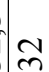 \\
\hline $\begin{array}{r}\text { 51. Ширина орбиты } \\
\text { (правая) }\end{array}$ & $\begin{array}{l}n \\
n \\
\gamma\end{array} \mid$ & & 가 & $\stackrel{m}{\gamma}$ & & 守 & & 年 & 舀 & & & & & fr & & \\
\hline 51. Ширина орбиты (левая) & 导 & 孛 & $\stackrel{+}{\mathcal{T}}$ & $\stackrel{n}{q}$ & & 웅 & Z & $\frac{\gamma}{7}$ & $\nabla$ & $\stackrel{n}{\forall}$ & $\stackrel{n}{q}$ & ข & & $\begin{array}{ll}n \\
f \\
f\end{array}$ & $\begin{array}{l}0 \\
+ \\
\end{array}$ & m \\
\hline 54:55. Носовой указатель & กี่ & & & & $\tilde{q}$ & $\vec{q}$ & 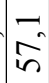 & $\overrightarrow{4}$ & $\left|\begin{array}{c}m \\
\infty \\
\infty\end{array}\right|$ & $\begin{array}{c}\sigma_{n} \\
\dot{\gamma} \\
\dot{\gamma}\end{array}$ & $\begin{array}{l}a \\
\text { in }\end{array}$ & g) & $\begin{array}{c}m \\
\infty \\
\infty\end{array}$ & $\begin{array}{l}\infty \\
i \\
n\end{array}$ & $\underset{+}{+}$ & 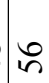 \\
\hline 54. Ширина носа & ৯े & & $\approx$ & & $\approx$ & ป & $\stackrel{\infty}{\sim}$ & 孛 & $\infty$ & $\stackrel{\sim}{\sim}$ & $\vec{n}$ & $\stackrel{n}{\stackrel{n}{s}}$ & $\infty$ & $\underset{\sim}{\sim}$ & 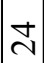 & $\infty$ \\
\hline 55. Высота носа & $n$ & & & & ชู & $\bar{n}$ & $g$ & in & $\infty$ & $n$ & $6^{\circ}$ & 요 & $\infty$ & $n$ & 으 & 윤 \\
\hline 63:62. Небный указатель & $\infty$ & & & & $\left|\begin{array}{l}0 \\
\infty \\
\infty\end{array}\right|$ & ชู & $\infty$ & & & & & & & & $\vec{\sigma}$ & \\
\hline 63. Ширина неба & $\stackrel{\infty}{+}$ & & & & ले & m & $\infty$ & $\infty$ & 암 & $m$ & & & & & $\vec{\gamma}$ & \\
\hline 62. Длина неба & in & & & & 寸 & ก & ช & & & & & & & & $\mathscr{\wp}$ & in \\
\hline $\begin{array}{r}\text { 61:6. Альвеолярный } \\
\text { указатель }\end{array}$ & $\begin{array}{l}\nabla_{0} \\
\text { ב } \\
-1\end{array}$ & & & & in & & $\begin{array}{l}\sim \\
\approx\end{array}$ & & $\begin{array}{l}\nabla_{0} \\
\stackrel{0}{\beth}\end{array}$ & an & & & & & $\underline{\underline{6}}$ & $\begin{array}{l}0 \\
=\end{array}$ \\
\hline $\begin{array}{r}\text { 61. Ширина альвеолярной } \\
\text { дуги }\end{array}$ & $\nabla$ & & & & $\overline{6}$ & J & 8 & $\overline{6}$ & 6 & ชู & 6 & & 6 & & 6 & 8 \\
\hline $\begin{array}{r}\text { 60. Длина альвеолярной } \\
\text { дуги }\end{array}$ & $\begin{array}{l}\infty \\
i\end{array}$ & & & & $n$ & & $n$ & & in & กี & & & & & in & $\bar{n}$ \\
\hline 46. Средняя ширина лица & $\stackrel{3}{0}$ & & $\infty$ & $\infty$ & & ○ & $a$ & $\hat{a}$ & $\left|\begin{array}{c}n \\
6 \\
2\end{array}\right|$ & মே & ลे & ๙๐ & & & $\underline{0}$ & \\
\hline 43. Верхняя ширина лица & 二 & $\Xi$ & $\overline{0}$ & 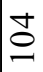 & $\stackrel{0}{0}$ & 莺 & 三 & 8 & $\stackrel{0}{=}$ & 工 & $\because$ & $\stackrel{9}{-}$ & & $\stackrel{\sim}{\Xi}$ & $\cong$ & 2 \\
\hline 48:45. Лицевой указатель & $\frac{\gamma}{\tilde{z}}$ & $\begin{array}{l}0 \\
n \\
n\end{array}$ & & & $\begin{array}{l}\infty \\
\infty \\
\infty\end{array}$ & & $\begin{array}{l}\hat{\sigma} \\
\infty \\
+\end{array}$ & 8 & & $\widehat{6}$ & $\left|\begin{array}{l}0 \\
0 \\
0\end{array}\right|$ & $\begin{array}{l}0 \\
g \\
q\end{array}$ & nn & $\frac{\sigma_{n}}{n}$ & $\begin{array}{c}m \\
\infty \\
+\end{array}$ & \\
\hline $\begin{array}{r}\text { 48:17. Краниофациальный } \\
\text { указатель }\end{array}$ & 点 & a & & & $\hat{n}$ & & $\frac{n}{q}$ & $\mid \begin{array}{l}0 \\
0 \\
n\end{array}$ & & & & & $\mid \begin{array}{l}m \\
\stackrel{n}{n}\end{array}$ & & $\mid \begin{array}{c}0 \\
\infty \\
+\end{array}$ & \\
\hline 48. Верхняя высота лица & $\mathbb{N}$ & 去 & & & n & 辛 & 6 & $\infty$ & $\nabla$ & $\begin{array}{l}n \\
6 \\
2\end{array}$ & $\frac{n}{2}$ & ஜ & 12 & $n$ & $\approx$ & 8 \\
\hline $\begin{array}{r}\text { 40:5. Указатель } \\
\text { выступания лица }\end{array}$ & 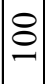 & $\stackrel{n}{a}$ & & & & & $\begin{array}{l}2 \\
0 \\
0\end{array}$ & $\left|\begin{array}{l}n \\
\infty \\
\infty\end{array}\right|$ & & & & & & & 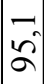 & \\
\hline 40. Длина основания лица & $\stackrel{2}{0}$ & $\stackrel{\infty}{0}$ & & & & & 음 & สู & & & & & & & $\hat{a}$ & \\
\hline № ח/П & - & $\mathrm{N}$ & $m$ & $\nabla$ & in & 6 & $r$ & $\infty$ & $a$ & 으 & $=$ & 工 & $\cong$ & $\Xi$ & $\because$ & 0 \\
\hline
\end{tabular}


М.А. Балабанова. К антропологии населения энеолита - ранней бронзы

\begin{tabular}{|c|c|c|c|c|c|c|c|c|c|c|c|c|c|c|c|c|}
\hline 75-1. Угол выступания носа & iి & $m$ & & & & & $\approx$ & & & fo & & & & $\vec{m}$ & $\hat{n}$ & $\infty$ \\
\hline $\begin{array}{r}\text { 75. Угол наклона носовых } \\
\text { костей }\end{array}$ & $n$ & $\bar{n}$ & & & & & オ & & & 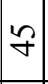 & & & & $\stackrel{\bullet}{n}$ & $\underset{+}{\infty}$ & \\
\hline 74. Угол альвеолярной части & 인 & $\infty$ & & & & & (6) & $\curvearrowright$ & & $\hat{n}$ & $\infty$ & ஓ & & \$ & $\infty$ & \\
\hline 73. Средний лицевой угол & $\infty$ & $\infty$ & & & & & ஃ & $\infty$ & & 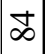 & $\infty$ & $\infty$ & & $\infty$ & $\infty$ & \\
\hline 72. Общий лицевой угол & $\infty$ & $\infty$ & & & & & $\infty$ & $\infty$ & & $\infty$ & $\infty$ & $\infty$ & & $\infty$ & $\infty$ & \\
\hline $\begin{array}{r}\text { Угол профиля лба от } \\
\text { глабеллы }\end{array}$ & $\nabla$ & $\hat{\infty}$ & & & & & 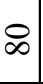 & 6 & & $\approx$ & $n$ & t & & 6 & 去 & \\
\hline $\begin{array}{r}\text { 32. Угол профиля лба назион } \\
- \text { метопион }\end{array}$ & $\infty$ & $\infty$ & & & & & $\infty$ & $N$ & & $\infty$ & $\curvearrowright$ & 6 & & $n$ & 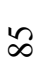 & \\
\hline $\begin{array}{r}\text { FC (глубина клыковой ямки } \\
\text { (правая)) }\end{array}$ & $n$ & & & & & & & 6 & $\stackrel{n}{\sim}$ & $\sim$ & & & & $n$ & & \\
\hline $\begin{array}{r}\text { FC (глубина клыковой ямки } \\
\text { (левая)) }\end{array}$ & 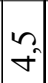 & - & 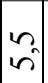 & & & $\left(\begin{array}{c}n \\
6\end{array}\right.$ & भ̊? & $\sim$ & & $n$ & $n$ & $\sim$ & $\vec{n}$ & & $\begin{array}{l}\infty \\
i\end{array}$ & \\
\hline $\begin{array}{r}\text { DS:DC (дакриальный } \\
\text { указатель) }\end{array}$ & 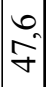 & & & & & $\vec{n}$ & $\begin{array}{l}\text { กิ } \\
\qquad\end{array}$ & & & & & & & $\begin{array}{l}\mathcal{f} \\
f\end{array}$ & 8 & $\begin{array}{l}\infty \\
\text { mீ }\end{array}$ \\
\hline DS (дакриальная высота) & $=$ & & & & & ב & $\stackrel{\nabla_{0}}{=}$ & & & & & & & $\cong$ & $\infty$ & $\ddot{n}$ \\
\hline DC (дакриальная ширина) & $\curvearrowright$ & & & & & $\vec{\sim}$ & ڤి & $\overrightarrow{\overbrace{}^{0}}$ & & & & & & ㄴ. & $\approx$ & ָֻ \\
\hline $\begin{array}{r}\text { MS:MC } \\
\text { (максилофронтальный } \\
\text { указатель) }\end{array}$ & ले & à & in & $\begin{array}{l}\sim \\
\tilde{m}\end{array}$ & & $\begin{array}{l}0 \\
\hat{n} \\
n\end{array}$ & $\begin{array}{c}0 \\
\infty \\
m\end{array}$ & & & $\vec{F}$ & & & & $\begin{array}{ll}n \\
2 \\
2\end{array}$ & 우 & ูู \\
\hline $\begin{array}{r}\text { MS (максилофронтальная } \\
\text { высота) }\end{array}$ & $a$ & $n^{2}$ & $\mid$ & $\hat{\sigma}^{\circ}$ & & $\mid$ & $\sim$ & & & a & & & & कृ & $\infty$ & ?ु? \\
\hline $\begin{array}{r}\text { МС (максилофронтальная } \\
\text { ширина) }\end{array}$ & $\approx$ & $\hat{n}^{m}$ & 6 & $\begin{array}{l}0 \\
2\end{array}$ & & $\mid$ & $\begin{array}{l}\nabla_{0} \\
\infty\end{array}$ & $\vec{\sim}$ & 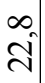 & 2 & $\approx$ & & & $\begin{array}{l}\infty \\
\hat{n}^{\infty}\end{array}$ & ণ & $\underset{\substack{+\infty}}{+}$ \\
\hline $\begin{array}{r}\text { SS:SC (симотический } \\
\text { указатель) }\end{array}$ & $\stackrel{m}{n}$ & 8 & 2 & $\begin{array}{l}\hat{0} \\
\hat{n}\end{array}$ & & $\begin{array}{c}m \\
\infty \\
q\end{array}$ & $\tilde{n}$ & & & $\frac{\Omega}{2}$ & & & & $\begin{array}{c}\sim \\
n \\
n\end{array}$ & $n$ & $\stackrel{0}{\sim}$ \\
\hline SS (симотическая высота) & ले & के & $\mid \begin{array}{ll}n \\
f\end{array}$ & $\infty$ & & $\begin{array}{l}2 \\
\sim \\
\sim\end{array}$ & & & & 6 & & & & 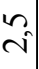 & m & $\sim$ \\
\hline SC (симотическая ширина) & 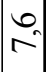 & 으 & 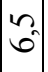 & $\hat{\sigma}$ & $\vec{\sim}$ & 2 & $\tilde{\infty}$ & $a$ & $\tilde{n}$ & $r$ & & $m$ & & $\overrightarrow{2}$ & 으 & an \\
\hline $\begin{array}{r}<\mathrm{zm} \text { ' (зигомаксилярный } \\
\text { угол) }\end{array}$ & 索 & & & & & $\begin{array}{l}\hat{\sigma} \\
\stackrel{0}{0}\end{array}$ & 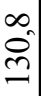 & 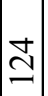 & ปิ & ปู & $\begin{array}{l}0 \\
n \\
=\end{array}$ & fin & & & 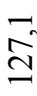 & \\
\hline Зигомаксилярный указатель & $\vec{\sim}$ & & & & & $\approx$ & $\frac{\sigma}{\lambda}$ & (ิ) & $\overbrace{}^{\infty}$ & - & $\frac{n}{n}$ & in & & & 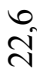 & \\
\hline $\begin{array}{r}\text { Высота над точкой } \\
\text { субспинале }\end{array}$ & 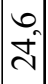 & & & & & 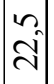 & ָे & $\approx$ & $\tilde{\lambda}$ & 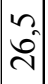 & $\bar{m}$ & $\because$ & & & $\approx$ & \\
\hline Зигомаксилярная ширина & n̊ & & & $\infty$ & & ৪ & สิ & $\begin{array}{l}\infty \\
2\end{array}$ & そุ & वं & $\begin{array}{l}\nabla_{\alpha} \\
\infty \\
\sigma\end{array}$ & 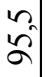 & & & ฮิ & \\
\hline 77. Назомалярный угол & 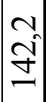 & $\begin{array}{l}\infty \\
\infty \\
m\end{array}$ & $\hat{m}$ & 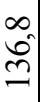 & 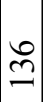 & $\vec{f}$ & $\begin{array}{l}0 \\
\stackrel{2}{2}\end{array}$ & $\vec{m}$ & $\begin{array}{l}\nabla \\
0 \\
\check{\nu}\end{array}$ & $\begin{array}{l}\tilde{n} \\
\hat{n}\end{array}$ & $\begin{array}{l}\infty \\
0 \\
ల \\
=\end{array}$ & $\stackrel{0}{\stackrel{0}{=}}$ & $\begin{array}{c}m \\
2 \\
\beth\end{array}$ & 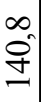 & $\begin{array}{l}\text { N } \\
\text { \&े } \\
\end{array}$ & $\begin{array}{l}\forall \\
\text { ळे }\end{array}$ \\
\hline № п/п & -1 & $N$ & $m$ & $\nabla$ & $n$ & 0 & $r$ & $\infty$ & $a$ & 0 & $=$ & $\simeq$ & 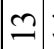 & \pm & 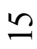 & $\underset{\imath}{0}$ \\
\hline
\end{tabular}


M.A. Balabanova. On the Anthropology of the Population of the Eneolithic - Early Bronze Age

\begin{tabular}{|c|c|c|c|c|c|c|c|c|c|c|c|c|c|c|c|c|}
\hline Передненосовая ость & $\sim$ & & & & & $m$ & - & $m$ & & in & $m$ & $m$ & $m$ & $m$ & $m$ & $\sim$ \\
\hline $\begin{array}{r}\text { Нижний край грушевидного } \\
\text { отверстия }\end{array}$ & 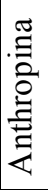 & 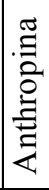 & & & 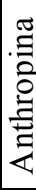 & 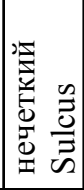 & 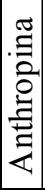 & 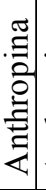 & 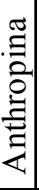 & 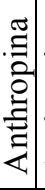 & 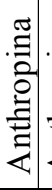 & 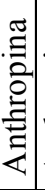 & 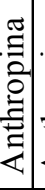 & 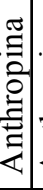 & & 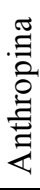 \\
\hline Сосцевидный отросток (1-3) & $\sim$ & $\sim$ & & - & - & $N$ & $\stackrel{\infty}{i}$ & $v$ & $v$ & $m$ & $m$ & 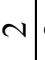 & $v$ & $\mathrm{~N}$ & $n$. & - \\
\hline $\begin{array}{r}\text { Наружный затылочный бугор } \\
\text { (по Брока) }\end{array}$ & $m$ & $m$ & & - & - & - & 一 & ? & $\nabla$ & - & $\nabla$ & -1 & $n$ & $m$ & $n$ & \\
\hline Надбровные дуги (1-3) & $\sim$ & $\sim$ & & - & N & - & $m$ & ชิ & ñ & $\sim$ & $m$ & व̂. & ๙2) & N & $n$ & \\
\hline Надпереносье по Мартину & $n$ & $\nabla$ & & $N$ & $m$ & & $m$ & $\nabla$ & $\nabla$ & $\nabla$ & $\nabla$ & $m$ & $m$. & $\nabla$ & $n$ & \\
\hline Форма черепа сверху & 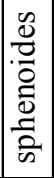 & & $\begin{array}{l}\frac{2}{0} \\
\frac{0}{0} \\
\frac{0}{0} \\
\frac{0}{2} \\
\frac{0}{n}\end{array}$ & $\begin{array}{l}0 \\
\frac{0}{0} \\
\frac{0}{0} \\
0 \\
0 \\
\frac{1}{2} \\
\frac{1}{n}\end{array}$ & $\begin{array}{l}0 \\
\frac{0}{0} \\
0 \\
0 \\
\vdots \\
0\end{array}$ & 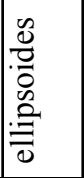 & & 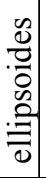 & 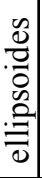 & $\begin{array}{c} \\
\mathscr{0} \\
\frac{0}{0} \\
0 \\
0 \\
0\end{array}$ & $\mid \begin{array}{l}0 \\
\frac{0}{0} \\
\frac{0}{0} \\
0 \\
\frac{1}{2} \\
\frac{2}{\infty}\end{array}$ & 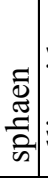 & $\begin{array}{l}0 \\
0 \\
0 \\
0 \\
0 \\
0 \\
0 \\
0 \\
0\end{array}$ & 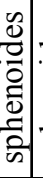 & 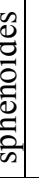 & \\
\hline № п/п & - & 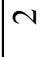 & $m$ & $\nabla$ & $n$ & 6 & $r$ & $\infty$ & a & 으 & $=$ & 工 & $\approx$. & \pm & 2 & 0 \\
\hline
\end{tabular}


М.А. Балабанова. К антропологии населения энеолита - ранней бронзы

\section{Средние значения краниологических признаков мужских серий}

ямной культуры

\begin{tabular}{|c|c|c|c|c|c|c|c|c|c|c|}
\hline \multirow{2}{*}{$\begin{array}{c}\text { № по Мартину } \\
\text { и др. }\end{array}$} & \multicolumn{5}{|c|}{ Ранняя группа } & \multicolumn{5}{|c|}{ Поздняя группа } \\
\hline & $\mathrm{n}$ & $\mathrm{X}$ & $\mathrm{s}$ & Max & Min & $\mathrm{n}$ & $\mathrm{X}$ & $\mathrm{s}$ & Max & Min \\
\hline 1 & 4 & 188,8 & 4,6 & 195 & 184 & 13 & 188,5 & 6,6 & 200 & 180 \\
\hline 8 & 4 & 139,25 & 3,9 & 145 & 136 & 13 & 140,1 & 6,3 & 150 & 128 \\
\hline $8: 1$ & 4 & 73,8 & 2,6 & 77,1 & 70,8 & 13 & 74,4 & 5,1 & 82,4 & 64,3 \\
\hline 17 & 3 & 139,7 & 9,9 & 151 & 133 & 5 & 140,2 & 4,0 & 146 & 136 \\
\hline $17: 1$ & 3 & 73,85 & 3,4 & 77,4 & 70,7 & 5 & 74,7 & 3,0 & 78,9 & 71,4 \\
\hline $17: 8$ & 3 & 100,1 & 8,9 & 109,4 & 91,7 & 5 & 102,2 & 5,9 & 110,9 & 94,4 \\
\hline OPB & 3 & 273,5 & 8,6 & 282,6 & 265,7 & 5 & 271,8 & 4,0 & 276,2 & 267,6 \\
\hline M2 & 4 & 262,8 & 10,1 & 272,6 & 250,2 & 13 & 263,9 & 10,5 & 287,6 & 251,4 \\
\hline M3 & 3 & 1844,5 & 173,5 & 2031,7 & 1689,1 & 5 & 1806,9 & 84,1 & 1944,7 & 1721,9 \\
\hline 5 & 3 & 107 & 10,1 & 118 & 98 & 5 & 111,8 & 12,9 & 133 & 102 \\
\hline 20 & 4 & 116,8 & 3,1 & 121 & 114 & 7 & 120,4 & 4,3 & 124 & 112,5 \\
\hline 9 & 4 & 97,5 & 5,1 & 105 & 94 & 15 & 98,2 & 5,1 & 105 & 88 \\
\hline $9: 8$ & 4 & 70,0 & 1,9 & 72,4 & 68,1 & 13 & 70,9 & 4,2 & 76,5 & 62 \\
\hline $9: 10$ & 4 & 85,0 & 4,5 & 90,5 & 79,7 & 12 & 82,4 & 4,3 & 87,7 & 75,6 \\
\hline УПИЛ & 2 & 136,85 & 5,0 & 140,4 & 133,3 & 12 & 135,1 & 4,9 & 147 & 129,3 \\
\hline 10 & 4 & 114,8 & 3,0 & 118 & 111 & 14 & 118,9 & 8,0 & 133 & 105 \\
\hline 11 & 3 & 126,3 & 10,3 & 135 & 115 & 9 & 125,2 & 9,2 & 136 & 108 \\
\hline 12 & 3 & 108,7 & 4,6 & 114 & 106 & 9 & 110,2 & 5,2 & 116 & 101 \\
\hline $28: 27$ & 4 & 101,3 & 7,7 & 112,5 & 98,1 & 10 & 94,4 & 8,3 & 109,2 & 84,4 \\
\hline 45 & 4 & 138 & 9,4 & 151 & 129 & 10 & 135,2 & 10,1 & 147 & 113 \\
\hline 48 & 4 & 68,8 & 5,4 & 74 & 62 & 14 & 72,7 & 4,1 & 78 & 66 \\
\hline 54 & 3 & 25,7 & 2,9 & 29 & 24 & 15 & 26,3 & 2,5 & 31 & 22 \\
\hline 55 & 3 & 50,0 & 4,4 & 55 & 47 & 14 & 54,1 & 4,2 & 62 & 47 \\
\hline $55: 54$ & 3 & 51,3 & 1,4 & 52,7 & 50 & 14 & 49,0 & 5,2 & 57,1 & 42,1 \\
\hline 51 & 4 & 42,25 & 2,1 & 44 & 40 & 13 & 43,5 & 1,9 & 46 & 40 \\
\hline 52 & 4 & 31,6 & 0,5 & 32 & 31 & 14 & 33,3 & 1,9 & 37 & 29,5 \\
\hline $52: 51$ & 4 & 75,0 & 3,7 & 80 & 71,6 & 12 & 76,9 & 6,0 & 85,4 & 65,6 \\
\hline $\mathrm{DC}$ & 3 & 20,9 & 3,6 & 25 & 18,2 & 7 & 23,6 & 2,4 & 27 & 20,3 \\
\hline DS & 3 & 11,9 & 0,9 & 12,8 & 11,0 & 5 & 13,2 & 3 & 18,3 & 11,2 \\
\hline DS:DC & 3 & 58,1 & 11,5 & 70,3 & 47,6 & 5 & 57,6 & 11,2 & 74,7 & 44,2 \\
\hline $\mathrm{SC}$ & 4 & 8,2 & 1,2 & 10 & 7,4 & 11 & 8,9 & 1,8 & 12,1 & 6,5 \\
\hline $\mathrm{SS}$ & 4 & 5,35 & 1,2 & 6,9 & 3,9 & 8 & 4,85 & 1,6 & 7,8 & 2,5 \\
\hline SS:SC & 4 & 64,9 & 9,1 & 70,5 & 51,3 & 8 & 58,4 & 14,1 & 77,9 & 35,2 \\
\hline $\mathrm{FC}$ & 4 & 3,2 & 1,6 & 4,5 & 1,0 & 9 & 5,7 & 1,1 & 7,1 & 3,5 \\
\hline 77 & 4 & 139,4 & 3,2 & 142,2 & 135,6 & 15 & 137,1 & 5,8 & 145,3 & 123,3 \\
\hline$<\mathrm{zm}$ & 3 & 130,2 & 3,4 & 134 & 127,4 & 10 & 124,7 & 4,7 & 130,8 & 115,6 \\
\hline 32 & 4 & 82,8 & 4 & 87 & 78 & 8 & 78,5 & 5,1 & 86 & 72 \\
\hline 72 & 4 & 84,25 & 1,7 & 86 & 82 & 8 & 85,5 & 4,1 & 89 & 78 \\
\hline 74 & 4 & 77,5 & 7,0 & 86 & 70 & 8 & 74,1 & 13,5 & 89 & 53 \\
\hline $75-1$ & 4 & 36,0 & 4,5 & 40 & 30 & 5 & 37 & 9,2 & 46 & 25 \\
\hline
\end{tabular}


M.A. Balabanova. On the Anthropology of the Population of the Eneolithic - Early Bronze Age

Таблииа 3

Средние значения краниологических признаков женских серий ямной культуры

\begin{tabular}{|c|c|c|c|c|c|c|c|c|c|c|c|}
\hline $\begin{array}{c}\text { № по Мартину } \\
\text { и др. }\end{array}$ & $\mathrm{n}$ & $\mathrm{X}$ & $\mathrm{s}$ & $\mathrm{Max}$ & $\mathrm{Min}$ & $\begin{array}{c}\text { № по Мартину } \\
\text { и др. }\end{array}$ & $\mathrm{n}$ & $\mathrm{X}$ & $\mathrm{s}$ & Мax & Min \\
\hline 1 & 4 & 180 & 6,7 & 188 & 174 & 48 & 4 & 65 & 3,5 & 68 & 60 \\
\hline 8 & 4 & 140 & 3,6 & 143 & 136 & 54 & 4 & 24,9 & 2,2 & 28 & 23 \\
\hline $8: 1$ & 4 & 77,9 & 4,8 & 82,2 & 72,3 & 55 & 4 & 50,25 & 0,5 & 51 & 50 \\
\hline 17 & 2 & 137 & & 137 & 137 & $55: 54$ & 4 & 49,5 & 4,6 & 56 & 49,1 \\
\hline $17: 1$ & 2 & 73,9 & & 74,9 & 72,9 & 51 & 5 & 42,4 & 2,2 & 45 & 39 \\
\hline $17: 8$ & 2 & 100 & & 100,7 & 99,3 & 52 & 5 & 32,2 & 0,4 & 33 & 32 \\
\hline OРВ & 2 & 268,2 & & 269,5 & 267,0 & $52: 51$ & 5 & 76,1 & 4,2 & 82,05 & 71,1 \\
\hline М2 & 4 & 251,8 & 3,0 & 255,7 & 248,8 & DC & 3 & 22,4 & 7,0 & 30,2 & 16,8 \\
\hline М3 & 2 & 1740,6 & & 1751,4 & 1729,9 & DS & 3 & 10,0 & 0,5 & 10,5 & 9,5 \\
\hline 5 & 2 & 101 & & 104 & 98 & DS:DC & 3 & 46,9 & 11,1 & 56,5 & 34,8 \\
\hline 20 & 3 & 113,7 & 1,5 & 115 & 112 & SC & 5 & 8,0 & 3,25 & 13,0 & 5,0 \\
\hline 9 & 5 & 96,6 & 2,9 & 101 & 93 & SS & 4 & 3,2 & 0,9 & 4,1 & 2,0 \\
\hline $9: 8$ & 4 & 69,1 & 1,2 & 70,6 & 67,8 & SS:SC & 4 & 51,7 & 21,4 & 70,7 & 21,05 \\
\hline $9: 10$ & 4 & 83,8 & 4,4 & 88,1 & 78,9 & FC & 3 & 3,0 & 1,6 & 4,9 & 2,0 \\
\hline УПИЛ & 3 & 136,2 & 3,0 & 138 & 132,7 & 77 & 5 & 136,4 & 2,9 & 139,4 & 131,6 \\
\hline 10 & 4 & 115,8 & 9,0 & 124 & 107 & $<$ zm & 3 & 133,1 & 10,4 & 145,1 & 127,1 \\
\hline 11 & 4 & 122,5 & 5,4 & 129 & 116 & 32 & 3 & 78,7 & 10,1 & 85 & 67 \\
\hline 12 & 3 & 107 & 4,4 & 110 & 102 & 72 & 3 & 84 & 4,4 & 89 & 81 \\
\hline $28: 27$ & 4 & 99,9 & 6,9 & 109,2 & 94,3 & 74 & 3 & 81,3 & 6,7 & 89 & 77 \\
\hline 45 & 3 & 129,7 & 3,5 & 133 & 126 & $75-1$ & 3 & 24,7 & 5,9 & 29 & 18 \\
\hline
\end{tabular}


M.А. Балабанова. К антропологии населения энеолита - ранней бронзы

Список привлекаемых мужских краниологических групп для сравнительного анализа эпохи энеолита - бронзы

\begin{tabular}{|c|c|c|c|}
\hline \begin{tabular}{c|} 
№ \\
П/П
\end{tabular} & Группа, автор публикации & $\begin{array}{l}\text { № } \\
\text { П/П }\end{array}$ & убликации \\
\hline 1 & $\begin{array}{l}\text { Хвалынская культура (энеолит) } \\
\text { [Хохлов, 2010; Хохлов и др., 2016] }\end{array}$ & 13 & $\begin{array}{l}\text { Калмыцкая } \quad \text { группа } \\
\text { катакомбные } \\
\text { 1986; Кагр.) } \\
\text { [Шазарницкий, 2012] }\end{array}$ \\
\hline 2 & $\begin{array}{l}\text { Ямная культура / Волго-Уральская } \\
\text { лесостепь [Хохлов и др., 2016] }\end{array}$ & 14 & $\begin{array}{l}\text { Катакомбная культура / восточно- } \\
\text { маныческая группа (юг) }\end{array}$ \\
\hline 3 & $\begin{array}{l}\text { Ямная культура / Поволжская степь } \\
\text { [Хохлов и др., 2016] }\end{array}$ & 15 & $\begin{array}{l}\text { Катакомбная культура / восточно- } \\
\text { маныческая группа (север) [Шев- } \\
\text { ченко, 1986; Казарницкий, 2012] }\end{array}$ \\
\hline 4 & $\begin{array}{l}\text { Ямная культура / волгоградская } \\
\text { группа (ранняя) (материал автора) }\end{array}$ & 16 & $\begin{array}{l}\text { Донская группа } \\
\text { [Шевченко, 1986; } \\
\text { 2012] }\end{array}$ \\
\hline 5 & $\begin{array}{l}\text { Ямная культура / волгоградская } \\
\text { группа (поздняя) (материал автора) }\end{array}$ & 17 & $\begin{array}{l}\text { Катакомбная культура / новочер- } \\
\text { касская группа [Шевченко, 1986; } \\
\text { Казарницкий, 2012] }\end{array}$ \\
\hline 6 & $\begin{array}{l}\text { Ямная культура / чограйская группа } \\
\text { [Шевченко, 1986; Казарницкий, } \\
\text { 2012] }\end{array}$ & 18 & $\begin{array}{l}\text { Катакомбная культура / ростовская } \\
\text { группа [Шевченко, 1986; Казарниц- } \\
\text { кий, 2012] }\end{array}$ \\
\hline 7 & $\begin{array}{l}\text { Ямная культура / канал Волга - Чо- } \\
\text { грай [Шевченко, 1986; Казарницкий, } \\
\text { 2012] }\end{array}$ & 19 & $\begin{array}{l}\text { Катакомбная культура / ингульская } \\
\text { группа [Круц, 1984] }\end{array}$ \\
\hline 8 & $\begin{array}{l}\text { Ямная культура / калмыцкая группа } \\
\text { (суммар.) [Шевченко, 1986; Казар- } \\
\text { ницкий, 2012] }\end{array}$ & 20 & $\begin{array}{l}\text { Катакомбная культура / херсонская } \\
\text { группа [Круц, 1984] }\end{array}$ \\
\hline 9 & $\begin{array}{l}\text { Ямная культура / Кривая Лука } \\
\text { [Шевченко, 1986; Казарницкий, } \\
\text { 2012] }\end{array}$ & 21 & $\begin{array}{l}\text { Катакомбная культура / волгоград- } \\
\text { ская группа (суммар.) (материал } \\
\text { автора) }\end{array}$ \\
\hline 10 & $\begin{array}{l}\text { Ямная культура / Самарское Завол- } \\
\text { жье и Оренбуржье (ранняя) [Хох- } \\
\text { лов, 1999] }\end{array}$ & 22 & $\begin{array}{l}\text { Полтавкинская культура (суммар.) } \\
\text { [Хохлов и др., 2016] }\end{array}$ \\
\hline 11 & $\begin{array}{l}\text { Ямная культура / Самарское Завол- } \\
\text { жье и Оренбуржье (поздняя) [Хох- } \\
\text { лов, 1999] }\end{array}$ & 23 & $\begin{array}{l}\text { Новотитаровская культура (курган } \\
\text { «Овальный», погр. 35) (материал ав- } \\
\text { тора) }\end{array}$ \\
\hline 12 & $\begin{array}{l}\text { Катакомбная культура / калмыцкая } \\
\text { группа (ранние) [Шевченко, 1986; } \\
\text { Казарницкий, 2012] }\end{array}$ & 24 & $\begin{array}{l}\text { Майкопская культура [Шевченко, } \\
\text { 1986; Казарницкий, 2012] }\end{array}$ \\
\hline
\end{tabular}


M.A. Balabanova. On the Anthropology of the Population of the Eneolithic-Early Bronze Age

\section{ПРИМЕЧАНИЯ}

${ }^{1}$ Работа выполнена при поддержке гранта РФФИ № 15-06-01916.

${ }^{2}$ А.В. Кияшко также эти погребения не определяет как принадлежащие ямной культуре. Датировки и культурные определения всего материала, включенного в нашу серию, проведены А.В. Кияшко (в том числе и материалов бережновского могильника), за что мы ему благодарны.

${ }^{3}$ Индивидуальные значения краниологических признаков этого черепа приведены в коллективной монографии [Балабанова и др., 2014].

${ }^{4}$ Анализ патологического состояния скелета проведен канд. ист. наук Е. В. Перервой.

\section{СПИСОК ЛИТЕРАТУРЫ}

Алексеев В. П., Дебец Г. Ф. (1964). Краниометрия: Методика антропологических исследований. М. : Наука. 128 c.

Балабанова М. А., Перерва Е. В., Клепиков В. М., Кривошеев М. В., Скрипкин А. С., Дьяченко А. Н., Яворская Л. В. (2014). Курганный могильник Перегрузное I: результаты междисциплинарных исследований. Волгоград : Изд-во Волгогр. фил. РАНХиГС. 368 с.

Беневоленская Ю. Д. (1980). Мировое распределение затылочно-теменного указателя // Современные проблемы и новые методы в антропологии. Л. : Наука. С. 70-90.

Гинзбург В. В. (1959). Этногенетические связи древнего населения Сталинградского Заволжья (По материалам Калиновского могильника) // МИА. М. ; Л. : Изд-во АН СССР. № 60. C. 524-594.

Глазкова Н. М., Чтецов В. П. (1960). Палеоантропологические материалы Нижневолжского отряда Сталинградской экспедиции // МИА. М. ; Л. : Изд-во АНСССР. № 78. С. 286-292.

Дебец Г. Ф. (1936). Материалы по палеоантропологии СССР. Нижнее Поволжье // АЖ. № 1. C. $65-80$.

Дебец Г. Ф. (1948). Палеоантропология СССР. М. ; Л. : Изд-во АН СССР. 392 с. (ТИЭ ; т. 4).

Дьяченко А. Н. (1989). Отчет об археологических исследованиях курганного могильника «Орешкин I» в Михайловском районе Волгоградской области в 1989 году// Архив археологической лаборатории ВолГУ.

Дьяченко А. Н., Мэйб Э., Скрипкин А. С., Клепиков В. М. (1999). Археологические исследования в Волго-Донском междуречье // Нижневолжский археологический вестник. Вып. 2. Волгоград. С. 93-126.
Казарницкий А. А. (2012). Население Азово-Каспийских степей в эпоху бронзы (антропологический очерк). СПб. : Наука. 264 с.

Козинцев А. Г. (1988). Этническая краниоскопия: расовая изменчивость швов черепа современного человека. Л. : Наука. 167 с.

Круц С. И. (1984). Палеоантропологические исследования степного Приднепровья (эпоха бронзы). Киев : Наукова думка. 208 с.

Мамонтов В. И. (1986 ). Отчет о работе Приволжского отряда ЛОИА АН СССР в 1986 г. // Архив ВОКМ. № 50 .

Мамонтов В. И. (1989). Отчет о работе Приволжского отряда ЛОИА АН СССР и Донской экспедиции ВГПИза 1989 г. // Архив ВОКМ. № 63.

Мамонтов В. И. (1998). Материалы курганного могильника «Новый Рогачик» // Нижневолжский археологический вестник. Вып. 1. Волгоград. С. 87-103.

Мамонтов В. И. (2001). Курганный могильник Первомайский VIII // Нижневолжский археологический вестник. Вып. 4. Волгоград. С. 179-195.

Мамонтов В. И. (2011). Одиночные курганы в окрестности поселка Водянского Октябрьского района // Нижневолжский археологический вестник. Вып. 12. Волгоград. С. 158-168.

Мыськов Е. П. (1989). Отчет о раскопках могильника Царев, проведенных Волго-Ахтубинским отрядом археологической экспедиции Волгоградского пединститута в 1989 г. // Архив ВОКМ. № 62 .

Назаров А. А. (1998). Охранные археологические раскопки кургана «Майоровский-1998» в Суровикинском районе; археологические разведки на территории Жирновского, Котовского, Дубовского, Камышинского районов в 1998 г. // Архив ВОКМ. № 240.

Сергацков И. В. (1991). Отчет о раскопках Иловлинской археологической экспедиции Волгоградского государственного университета в 1991 г. // Архив археологической лаборатории ВолГУ.

Шевченко А. В. (1986). Антропология населения южно-русских степей в эпоху бронзы // Антропология современного и древнего населения европейской части СССР. Л. С. 121-215.

Фирштейн Б. В. (1967). Антропологическая характеристика населения Нижнего Поволжья в эпоху бронзы // Памятники эпохи бронзы юга европейской части СССР. Киев. С. 100-139.

Хохлов А. А. (1999). Краниологические материалы ранней и начала средней бронзы самарского Заволжья и Оренбуржья // Вестник антропологии. М. : Старый сад. Вып. 6. С. 97-129.

Хохлов А. А. (2010). Население хвалынской энеолитической культуры: По антропологическим материалам грунтовых могильников Хва- 
лынск I, Хвалынск II, Хлопков Бугор // Хвалынские энеолитические могильники и хвалынская энеолитическая культура. Самара : Поволжье. С. 407-517.

Хохлов А. А. (2013). Краниологические материалы из древнейших подкурганных захоронений бережновского типа // Известия СНЦ РАН. Самара : Самар. науч. центр. Т. 15, № 1. С. 196-199.

Хохлов А. А., Солодовников К. Н., Рыкун М. П., Кравченко Г. Г., Китов Е. П. (2016). Краниологические данные к проблеме связи популяций ямной и афанасьевской культур Евразии начального этапа бронзового века // Вестник археологии, антропологии и этнографии. № 3 (34). C. 96-106.

\section{REFERENCES}

Alekseev V.P., Debets G.F. (1964). Craniometry: methods of anthropological research. Moscow, Nauka Publ. 128 p. (in Russian).

Balabanova M.A., Pererva E.V., Klepikov V.M., Krivosheev M.V., Demkin V.A., Eltsov M.V., Skripkin A.S., Udaltsov S.N. Yavorskaya L.V., Dyachenko A.N. (2014). Peregruznoe I burial mound: results of interdisciplinary research. Volgograd, Izd-vo Volgogradskogo filiala RANKHiGS. 360 p. (in Russian).

Benevolenskaya Yu.D. (1980). World distribution of the occipital and parietal index. Modern problems and new methods in anthropology. Leningrad, Nauka Publ., pp. 70-90. (in Russian).

Ginzburg V.V. (1959). Ethnogenetic connections of the ancient population of the Stalingrad Zavolzhye (On materials of the Kalinovsky burial ground). Materials and research on USSR archaeology. Moscow; Leningrad, AN SSSR Publ., no. 60, pp. 524-594. (in Russian).

Glazkova N.M., Chtesov V.P. (1960). Paleoanthropological materials of the Lower Volga group of the Stalingrad expedition. Materials and research on USSR archaeology. Moscow, Leningrad, AN SSSR Publ., no. 78, pp. 286-292. (in Russian).

Debets G.F. (1936). Materials on paleoanthropology of the USSR. Lower Volga area. Anthropological journal, no. 1, pp. 65-80. (in Russian).

Debets G.F. (1948). Paleoanthropology of the USSR. Moscow; Leningrad, AN SSSR Publ. 392 p. (Works; vol. 4). (in Russian).

Dyachenko A.N. (1989). The report on archaeological research of a burial ground "Oreshkin-I-89" in Mikhaylovsky district of the Volgograd region in 1989. Archive of arhaeological laboratory of VolSU. (in Russian).
DyachenkoA.N., MehjbAH., Skripkin A.S., Klepikov V.M. (1999). Archaeological research in Volga-Don interfluve. The Lower Volga archaeological bulletin, iss. 2, pp. 93-126. (in Russian).

Kazarnickiy A.A. (2012). Population of the AzovCaspian steppes in the Bronze Age: (Anthropological essay). St. Petersburg, Nauka Publ. 264 p. (in Russian).

Kozintsev A.G. (1988). Ethnic cranioscopy: racial variability of seams of a skull of a modern man. Leningrad, Nauka Publ. 167 p. (in Russian).

Kruts S.I. (1984). Paleoanthropological research of the Steppe Cis-Dnieper region (Bronze Age). Kiev, Naukova dumka Publ. 208 p. (in Russian).

Mamontov V.I. (1986). The report on work of the Volga group of LOIAAcademy of Sciences of the USSR in 1986. Archive of VOKM, no. 50. (in Russian).

Mamontov V.I. (1989). The report on work of the Volga group of LOIA Academy of Sciences and the Don expedition VSPI for 1989. Archive of VOKM, no. 63. (in Russian).

Mamontov V.I. (1998). Materials of the New Rogachik burial ground. The Lower Volga archaeological bulletin, iss. 1, pp. 87-103. (in Russian).

Mamontov V.I. (2001). Pervomayskiy VIII burial ground. The Lower Volga archaeological bulletin, iss. 4, pp. 179-195. (in Russian).

Mamontov V.I. (2011). Single barrows in the neighborhood of the settlement of Vodyansky of the Oktyabrsky district. The Lower Volga archaeological bulletin, iss. 12, pp. 158-168. (in Russian).

Myskov E.P. (1989). Report on the excavations of the Tsarev burial conducted by the Volga-Akhtuba detachment of archaeological expedition of Volgograd pedagogical Institute in 1989. Archive of VOKM, no. 62. (in Russian).

Nazarov A.A. (1998). Rescue archaeological excavations of the mound "Mayorovskiy-1998" in Surovikinsky area; archaeological survey in the territory of Zhirnovsky, Kotovsk, Dubovsky, Kamyshin areas in 1998. Archive of VOKM, no. 240. (in Russian).

Sergatskov I.V. (1991). The report on excavation of Ilovlinsky archaeological expedition of the Volgograd State University in 1991. Archive of arhaeological laboratory of VolSU. (in Russian).

Shevchenko A.V. (1986). Anthropology of the SouthRussian steppes population in the Bronze Age. Anthropology of ancient and modern population of the European part of the USSR. Leningrad, Nauka Publ.,pp. 121-215. (in Russian).

Firshteyn B.V. (1967). The anthropological characteristic of the population of Lower Volga area during the Bronze Age. Monuments of the Bronze Age from the South of USSR E+uropean part. Kiev Nauka Publ., pp. 100-139. (in Russian). 
M.A. Balabanova. On the Anthropology of the Population of the Eneolithic - Early Bronze Age

Khohlov A.A. (1999). Craniological materials of early and beginnings of Middle Bronze Age of the Samara Zavolzhye and the Orenburg region. Bulletin of anthropology. Moscow, Staryy sad Publ., vol. 6, pp. 97-129. (in Russian).

Khohlov A.A. (2010). Population of the Khvalynsk Eneolithic culture: according to anthropological materials from ground burials Khvalynsk I, Khvalynsk II, Khlopkov Bugor. Khvalynskie eneolithic barrows and khvalynskaya eneolithic culture. Samara, Povolzhye Publ., pp. 407-517. (in Russian).
Khohlov A.A. (2013). Craniological materials from ancient burials of Berezhnovka type. News of Samara scientific centre of RAS. Samara, Samarskiy Nauchnyy Centr Publ., vol. 15, no. 1, pp. 196-199. (in Russian).

Khohlov A.A., Solodovnikov K.N., Rykun M.P., Kravchenko G.G., Kitov E.P. (2016). Craniological data on a problem of communication of populations of pit and afanasyevsky cultures of Eurasia at the initial stage of the bronze age. Bulletin of archaeology, anthropology and ethnography, no. 3 (34), pp. 96-106. (in Russian).

\section{Information about the Author}

Mariya A. Balabanova, Doctor of Sciences (History), Head of Department of Archaeology, Foreign History and Tourism, Volgograd State University, Prosp. Universitetsky, 100, 400062 Volgograd, Russian Federation, mary_balabanova@mail.ru, adsi@volsu.ru.

\section{Информация об авторе}

Мария Афанасьевна Балабанова, доктор исторических наук, заведующий кафедрой археологии, зарубежной истории и туризма, Волгоградский государственный университет, просп. Университетский, 100, 400062 г. Волгоград, Российская Федерация, mary_balabanova@mail.ru, adsi@volsu.ru.

Citation. Balabanova M.A. (2016). On the Anthropology of the Population of the Eneolithic - Early Bronze Age (on Materials of Burial Grounds of the Volgograd Region). The Lower Volga Arhaeological Bulletin, vol. 15, no. 1, pp. 72-94. (in Russian). 